NBER WORKING PAPER SERIES

\title{
REGULATING EXECUTIVE PAY: USING THE TAX CODE TO INFLUENCE CEO COMPENSATION
}

\author{
Nancy L. Rose \\ Catherine Wolfram \\ Working Paper 7842 \\ http://www.nber.org/papers/w7842
NATIONAL BUREAU OF ECONOMIC RESEARCH 1050 Massachusetts Avenue
Cambridge, MA 02138

August 2000

\begin{abstract}
We gratefully acknowledge financial support for this project from the National Science Foundation (NSF) and the American Compensation Association (ACA) Emerging Scholar program. We thank Kate Meneely, Veronica Weiner, Jessica Wu and especially Janice Seinfeld for data assistance. This work has benefited from the comments of numerous colleagues, and in particular Henry Farber, Austan Goolsbee, Kevin J. Murphy, and participants in the March 2000 ACA Academic Research Conference and the MIT/Harvard Industrial Organization workshop. The views expressed are solely the authors' and do not reflect those of the NSF, the ACA, or the NBER.

(C) 2000 by Nancy L. Rose and Catherine Wolfram. All rights reserved. Short sections of text, not to exceed two paragraphs, may be quoted without explicit permission provided that full credit, including (C) notice, is given to the source.
\end{abstract}


Regulating Executive Pay:

Using the Tax Code to Influence CEO Compensation

Nancy L. Rose and Catherine Wolfram

NBER Working Paper No. 7842

August 2000

JEL No. J33, G3, L51, H2

\begin{abstract}
$\underline{\text { ABSTRACT }}$
This study explores corporate responses to 1993 legislation, implemented as section 162(m) of the Internal Revenue Code, that capped the corporate tax deductibility of top management compensation at $\$ 1$ million per executive unless it qualified as substantially "performance-based." We detail the provisions of this regulation, describe its possible effects, and test its impact on U.S. CEO compensation during the 1990s. Data on nearly 1400 publicly-traded U.S. corporations are used to explore the determinants of section $162(\mathrm{~m})$ compensation plan qualification and the effect of section $162(\mathrm{~m})$ on CEO pay. Our analysis suggests that section $162(\mathrm{~m})$ may have created a "focal point" for salary compensation, leading some salary compression close to the deductibility cap. There is weak evidence that compensation plan qualification is associated with higher growth rates, as would be the case if qualification relaxed some political constraints on executive pay. There is little evidence that the deductibility cap has had significant effects on overall executive compensation levels or growth rates at firms likely to be affected by the deductibility cap, however, nor is there evidence that it has increased the performance sensitivity of CEO pay at these firms. We conclude that corporate pay decisions seem to be relatively insulated from this type of blunt policy intervention.
\end{abstract}

Nancy L. Rose

MIT Economics Department

50 Memorial Drive, E52-371B

Cambridge, MA 02142-1347

and NBER

nrose@mit.edu
Catherine Wolfram

Haas School of Business

University of California

Berkeley, CA 94720-1900

and NBER

cdwolfram@yahoo.com 
The high and ever-increasing level of executive pay at U.S. corporations has come under substantial public attack over the past decade. ${ }^{1}$ This was particularly true during the 1992 presidential campaign, in which candidates from both political parties excoriated unmerited CEO pay (Birnbaum, 1992). Candidate Bill Clinton promised to prevent firms from taking corporate tax deductions for "excessive" payments to their CEOs, and realized this promise with a provision in the Omnibus Budget Reconciliation Act of 1993 (OBRA93) that eliminated corporate tax deductibility for compensation in excess of $\$ 1$ million for the CEO and each of the next four highest-paid executives within a firm. Proponents of this legislation argued that this would reduce "excessive" CEO pay by raising its cost to the corporation. The law exempted qualified "performance-based" compensation, however, which could mitigate these tax effects and induce changes in the structure of executive compensation plans. Moreover, given the broad scope for exemptions and the minimal impact tax deductibility of executive pay typically has on overall corporate profitability, the real impact of the tax cap on executive pay patterns remains an open question.

This study serves two broad purposes. First, we provide a detailed description of both the potential and real effects of the policy changes of the early 1990s. Academic research on executive compensation has increased dramatically through the 1990s (see Murphy, 2000). It is important to understand how the policy changes of 1993-1994 may influence empirical analyses. Second, by analyzing the effects of the tax cap, we consider the ability of corporations to make autonomous internal decisions in the face of public opprobrium. Stigler (1971) posited that the government would intervene in firm (and other) decisions in response to pressure from strong, well-organized interest groups. The analysis investigates the relative strength of corporate interests - both CEOs' economic self-interest and boards' interest in making unconstrained decisions for shareholders' benefit - and groups favoring greater income equality. In doing so, it adds to a growing literature that analyzes the impact of disclosure requirements and tax treatment of executive compensation. ${ }^{2}$

Previous academic work has noted the possible sensitivity of CEO compensation levels to political constraints. Jensen and Murphy (1990) speculated that political considerations may limit observed pay-for-performance, by constraining the extent to which a company can award its CEO large bonuses for good performance. ${ }^{3}$ To date, most direct empirical evidence of political constraints on executive pay has come from studies of regulated industries. Joskow, Rose and Shepard (1993) find evidence suggesting that CEOs of regulated firms are paid less, all else equal, because they face more intense political scrutiny. Joskow, Rose and Wolfram (1996) find that high

\footnotetext{
${ }^{1}$ These attacks have been launched from a broad cross-section of society: from compensation consultant Graef Crystal (1991) and former Harvard University president Derek Bok (1993), to institutional investors such as CALPERS and both Democratic and Republican politicians.

${ }^{2}$ See, for example, Lewellen et al. (1995), Murphy (1995, 1996), Johnson et al. (1997), Klassen and Mawani (1998), Baker (1999), Perry and Zenner (1999), Prevost and Wagster (1999), Goolsbee (2000), and Hall and Liebman (2000).

${ }^{3}$ See, however, Haubrich (1994), Hadlock and Lumer (1997) and Hall and Liebman (1997).
} 
Rose \& Wolfram - page 2

political pressure is associated with greater compensation discounts for electric utility CEOs, and Geddes (1997) finds that increased political pressure reduces executive tenure in this sector. Wolfram (1998) documents enormous salary increases for CEOs of U.K. electricity distribution companies following privatization, and argues that these reflect in part the loosening of political pressures as companies move from government- to private-ownership. A number of studies, particularly in the banking sector, have analyzed compensation changes in response to regulatory reforms that also affect firms' competitive environments (e.g., Barro and Barro, 1990, and Hubbard and Palia, 1995).

While these studies suggest that political constraints may limit executive compensation in the regulated arena, they provide no guidance as to whether political hostility to high pay also may constrain pay levels in industries not subject to economic regulation. For unregulated companies, there are few channels through which general public sentiment against high CEO pay can be expressed and ultimately influence compensation. ${ }^{4}$ Recent reforms have, however, created mechanisms that may induce boards of directors to account for public sentiment against high CEO pay when making their compensation decisions. The implementation of section $162(\mathrm{~m})$ of the Internal Revenue Code provides a useful test of the extent to which public sentiment and legislation in reaction to that sentiment can have real effects on CEO pay packages. Section 162(m) may have a direct effect on compensation by increasing the potential after-tax cost of CEO pay to the corporation. It also may have indirect effects, e.g., by inducing boards to change their compensation-setting processes. Some reports suggest that firms may have continued "compensation as usual," incurring higher after-tax costs (Lublin, 1994). Or, perhaps as former compensation consultant Graef Crystal (1995) has argued, "...by the time the lobbyists jumped in, the final regulations emasculated the law's intent" and section $162(\mathrm{~m})$ has had no real effect. The analysis in this paper adds to an emerging literature that attempts to understand how this legislation influenced executive pay, if at all (e.g., Johnson, Porter and Shackell, 1997; Perry and Zenner, 1999; and Hall and Liebman, 2000).

Section 1 details the provisions of section $162(\mathrm{~m})$ and describes their possible impact on executive pay. Section 2 discusses approaches to modeling the effect of section 162(m). Our empirical analysis and results are presented in section 3, and section 4 concludes.

\section{Limits on the corporate tax deductibility of CEO pay}

OBRA93, signed on August 10, 1993, added section 162(m) to the Internal Revenue Code (IRS $\uparrow 9001 \mathrm{~B}, \S 1.162$ ). This provision limits the corporate tax deduction for compensation paid to

\footnotetext{
${ }^{4}$ Individual shareholders may influence compensation through threatened resolutions or lawsuits; large stakeholders, including institutional investors, may directly pressure the board; and media reports on the firm may indirectly influence the process (see Johnson, et al., 1997). By contrast, a company that is subject to a cost-plus regulatory scheme may be "punished" for paying its CEO "too much" in several additional ways. For example, the regulator can decide to exclude all or part of executive compensation from recoverable costs or to use a low-end estimate of capital costs to calculate allowable rates of return.
} 
Rose \& Wolfram - page 3

the CEO and each of the next four highest-paid executive officers to $\$ 1$ million each, effective for compensation paid in tax years beginning on or after January $1,1994 .^{5}$ This cap represents roughly the median level of total compensation (valuing options at exercise), the $70^{\text {th }}$ percentile of cash compensation, and the $95^{\text {th }}$ percentile of salary over 1991-1993 for the 1282 firms in our full compensation data set.

OBRA93 provides for several exemptions from the million-dollar limit, however. Two are particularly noteworthy. ${ }^{6}$ First, the limit applies only to the five named executive officers of the firm as of fiscal-year-end. Compensation paid to executives who are not employed by the firm at fiscal year-end is not subject to the cap. This creates the possibility of using post-retirement or deferred compensation to mitigate the effect of the tax limits. If pay in excess of $\$ 1$ million is deferred until the CEO leaves the firm, the company will be able to claim the entire amount as a deductible expense when paid. From the CEO's perspective, the ability to compound deferred compensation at attractive tax-free interest rates inside the firm may make this option quite appealing. Potential liquidity constraints may somewhat reduce its attractiveness, the greater is deferred compensation relative to total compensation, and the longer is the time until expected retirement or departure from the firm. Some firms, particularly in the early post-OBRA93 years, encouraged or required executives to defer any portion of compensation in excess of $\$ 1$ million until post-retirement as a means of preserving full deductibility of executive pay. ${ }^{7}$ We have identified 87 firms out of a sample of 970 firms for which we have tax compliance information that

\footnotetext{
${ }^{5}$ Section 162(m) became effective with 1994 pay for firms with a December 31 fiscal-year-end, and with fiscal 1995 pay for all other firms, although final IRS regulations implementing this provision were not approved until December 19, 1995 (See T.D. 8650, corrected February 5, 1996). Standard \& Poors, our primary source for compensation and corporate financial information, records year as (fiscal year-1) for January through May fiscal-year-end firms. This implies that the effective date for firms with January through May fiscal-year-ends is our data year 1994 Compensation paid under binding contracts signed prior to February 1993 was exempt from the section 162(m) provisions for the term of those contracts, and companies operated under a variety of other transition rules during 1994 and 1995.

${ }^{6}$ Section $162(\mathrm{~m})$ applies only to compensation considered wage-based compensation under the Federal Insurance Contributions Act. Certain signing bonuses and other pre-employment payments may be structured to be exempt from section 162(m) limits.

${ }^{7}$ For example, Coastal Corporation's March 1995 proxy statement stated: "... at the present time, the CEO is the only executive whose base salary plus target bonus exceeds $\$ 1$ million. In order to preserve the Company's tax deduction for the CEO's base salary plus bonus, the Company has established a nonqualified deferred compensation program for Mr. Wyatt. Under this program, any annual incentive awards that bring Mr. Wyatt's cash compensation to a level over \$1 million will be deferred so that payments occur after Mr. Wyatt is no longer a Named Executive Officer, thus preserving the deductibility of the pay for the Company." George Wyatt retired from the CEO position the following year but maintained the position of Chairman of the Board. Coastal's 1996 proxy statement contained similar language to the 1995 statement, extending the deferral to the new CEO as well as to the Chairman.
} 
Rose \& Wolfram - page 4

explicitly referred in their proxy filings to using deferred compensation to maintain executive pay deductibility under section $162(\mathrm{~m})$.

More notable is the exemption for "qualified performance-based compensation" (IRS q9001B, §1.162-27(e)(1)). Qualification for this exemption requires, inter alia, advance shareholder approval of plans that base compensation on attainment of specific objective performance targets, and constitution of a compensation committee comprised solely of outside directors to oversee compensation plans and certify performance. Compensation paid under qualified plans is exempt from the cap, even if it exceeds $\$ 1$ million.

It is difficult to predict the effect of these requirements, and hence compensation plan qualification. At the simplest level, we might expect firms to use these exemptions to reduce their after-tax cost of executive compensation. Salary, which is non-contingent by definition, is subject to the cap unless deferred until the CEO has left the firm. Cash bonuses, stock awards, and stock option plans each may be structured as incentive plans and qualified for exemption. If the tax cost of paying non-deductible salary exceeds the implicit cost of qualifying performance-based pay, firms may shift from salary to tax-advantaged performance-based pay. This would tend to shift the compensation mix toward performance-based pay and away from salary as a fraction of total compensation.

Similarly, if the tax benefits of compensation payments under qualified plans exceed the costs of losing subjective discretion over bonus and long-term incentive payments, firms may substitute qualified compensation plans for less formal or more discretionary bonus or long-term incentive plans. This trade-off seems particularly to favor qualification of stock options plans, since this imposes little constraint on ex post option grants. Shareholders must approve just two parameters of a stock options plan to qualify: its overall size (total number of options during plan life) and the maximum (cumulative) limit on options to be awarded to any individual under the plan. Boards can then decide individual option awards on an annual basis, and options with exercise prices equal to or greater than the current stock price are considered to be entirely performance-based compensation. These features seem likely to increase the observed probability of qualifying options plans relative to qualifying other performance-based plans. The ease of qualifying options compensation may serve to further enhance the attractiveness of options compensation, which as Hall and Liebman (2000) note, already had accounting and modest tax advantages relative to cash compensation.

For cash-based performance pay under annual bonus or long-term incentive plans, qualification imposes more stringent constraints on ex post compensation decisions. ${ }^{8}$ To qualify, compensation must be paid "solely on account of the attainment of ... pre-established, objective performance goals," for which the outcome is "substantially uncertain," using an "objective formula

\footnotetext{
${ }^{8}$ Companies with qualified compensation plans may choose to set different levels of ex post compensation than would be generated by the plan, but then face additional tax liability if non-qualified compensation exceeds the cap.
} 
Rose \& Wolfram - page 5

or standard" (IRS $₫ 9001 \mathrm{~B}, \S 1.162-27(\mathrm{e})$ ). The proposed compensation plan and maximum amounts payable to individuals upon attainment of performance goals must be disclosed to and approved by shareholders before the compensation is awarded. ${ }^{9}$ Attainment of the performance goals must be certified by a compensation committee composed solely of "outsiders" on the Board of Directors. Qualification can impose real costs on firms by limiting the use of qualitative performance measures and Board discretion. ${ }^{10}$

This formulaic approach does not entirely eliminate Boards' discretion, however. Although the regulations do not exempt compensation paid in excess of the shareholder-approved plan, they explicitly allow firms to pay less than the plan would generate and maintain full deductibility (IRS q9001B, §1.162-27(e)(2)(iii)). Some practitioners have suggested that this may induce Boards to select ex ante more generous compensation plans to relax constraints imposed by the qualification regulations, knowing that they may scale ex post awards down, but not up. ${ }^{11}$

The predicted effect of section $162(\mathrm{~m})$ on the measured sensitivity of pay to performance at firms with qualified plans is ambiguous. Holding all else constant, a shift away from salary toward more performance-based pay will tend to increase the observed pay-for-performance sensitivity for overall compensation. Similarly, reducing discretionary pay components in bonus and long-term incentive plans and requiring payments to be linked to "objective" performance measures may generate payouts more closely related to conventional performance measures used in compensation

\footnotetext{
${ }^{9}$ The regulations allow companies considerable latitude in what details are disclosed to shareholders. For example, companies may maintain confidentiality of the specific numeric targets used to set performance goals, as well as the material terms of performance goals, if "the compensation committee determines that the information is confidential commercial or business information, the disclosure of which would have an adverse effect" on the firm (IRS $99001 \mathrm{~B}, \S 1.162-27(\mathrm{e})(4)(\mathrm{iii})$ ).

${ }^{10}$ For example, Gillette's 1995 proxy statement recommended shareholder approval of a modified stock options plan to qualify under section 162(m), but explicitly declined to modify their bonus plan, which awarded CEO Alfred Zeien a non-deductible \$1 million bonus payment on top of his \$1 million salary for fiscal year 1994. "The [Compensation] Committee has determined that to attempt to amend the Incentive Bonus Plan so that bonuses meet the definition of tax deductible compensation would require changes which would be contrary to the compensation philosophy underlying that plan and which would seriously impede the Committee's ability to administer the plan as designed in accordance with the judgement of the Committee. The Incentive Bonus Plan was deliberately designed so that individual bonuses were not to be dependent solely on objective or numerical criteria, thus allowing the Committee the flexibility to apply its independent judgement to reflect performance against qualitative strategic objectives." Gillette maintained this position through their latest (2000) proxy statement.

${ }^{11}$ Crystal (1995) noted: "...here's what some boards have done: They have deliberately adopted a bonus formula that produces far more money than they would ever expect to pay -- and then reduced the sum after the fact to what they would have paid had there been no government regulations at all. A case in point is Salomon Bros. In past years, the brokerage firm never gave its CEO a bonus of more than a few million dollars. Now it has adopted a formula that can pay him as much as \$24 million every year."
} 
Rose \& Wolfram - page 6

regressions. This would tend to raise the measured responsiveness of pay to these variables. On the other hand, all else may not be constant. If objective, non-discretionary compensation plans are perceived as generating greater compensation variance than would more discretionary awards of performance-based pay, particularly in low states over which executives may have little control or influence, boards may react to their reduced discretion by narrowing the range of payouts generated by plans. This could tend to offset, or perhaps even more than offset, compositional effects that increase the pay-for-performance sensitivity.

The expected effect of section $162(\mathrm{~m})$ on the level of executive pay is similarly difficult to sign. On the one hand, compensation that does not qualify for section 162(m) exemption becomes more expensive to the shareholders, as it cannot be treated as a deductible expense on corporate tax returns. The $\$ 1$ million cap also may serve as a focal point for the latent political hostility to high and rising executive pay levels, leading to some compression in executive pay, ceteris paribus. ${ }^{12}$ These factors suggest section 162(m) will depress compensation levels.

On the other hand, the implementation of the $\$ 1$ million cap appears to mitigate most of these pressures. While the initial rhetoric may have focused on pay levels, the final legislation seems to have been targeted more at reforming the compensation process and tilting toward performance-based pay than at constraining the level of executive compensation per se. In most simple models with risk-averse agents, this tilt toward riskier performance-based pay would suggest an increase, not decrease, in mean pay levels. Moreover, if Boards respond to the negative discretion option by selecting ex ante more generous compensation plans, but fail to scale formula awards back to the level the Board would have selected in the absence of the qualified plan, qualification may induce an additional, unintended, increase in compensation. These factors more than offset any downward pressures on compensation, leaving the level unchanged or higher than it would be without section $162(\mathrm{~m})$.

Given these competing forces and the resulting theoretical ambiguity, the actual effect of section $162(\mathrm{~m})$ on both the level and structure of executive pay can be determined only by empirical analysis of compensation outcomes. We turn next to a discussion of how to empirically test for its possible effects.

\section{Measuring the effects of section $162(\mathrm{~m})$}

Assessing the effects of section 162(m) requires us to establish an appropriate counterfactual: what would CEO pay have been after 1993 absent this provision? This type of counterfactual is difficult to establish in any policy analysis, and is particularly troublesome here. We discuss the advantages and disadvantages of several possible benchmarks below.

\footnotetext{
${ }^{12}$ It is possible that the cap raises pay that would otherwise be below $\$ 1$ million by creating the presumption that $\$ 1$ million is the "expected" level of CEO compensation. See Tversky and Kahneman's (1974) discussion of how the creation of focal points tends to bias expectations toward the focal point.
} 
Rose \& Wolfram - page 7

Before-and-after comparisons: One simple approach is to use time series variation in pay patterns to estimate "before and after" effects of section $162(\mathrm{~m})$. This seems unsatisfactory for a variety of reasons. First, as a general matter, executive pay patterns change over time for reasons wholly independent of tax policy (Hall and Liebman, 2000). If we attempt to measure policy effects by comparing pay levels, rates of increase, or even performance slopes before and after the policy change, we risk confounding the policy impact with other unrelated secular trends in compensation. Second, such a comparison is particularly troublesome in the case of section 162(m), which is almost contemporaneous with other policy changes that seem likely to independently influence executive pay. The proxy disclosure regulations issued by the Securities and Exchange Commission (SEC) in October 1992 and the OBRA93-related changes in personal and corporate income tax rates are particularly noteworthy.

The 1992 SEC regulations, which took effect with the 1993 proxy season, required substantially greater disclosure of executive compensation awards. ${ }^{13}$ Among the requirements were more detailed information on compensation components in the summary compensation table, including the number of stock options or stock appreciation rights awarded; provision of detailed information on and valuation of options grants in a separate table; inclusion of a line graph comparing the firm's shareholder return to that for a broad market index and a defined peer group of other firms; and a detailed discussion by the compensation committee of the basis of its compensation decisions. These reforms substantially enhanced disclosure, particularly of stock options grants, which have become an increasingly significant component of executive pay packages over the last 20 years (Hall and Liebman, 1998). In contrast to earlier regulations, the SEC now requires detailed information and valuation of options at the time they are awarded to executives. Firms have some discretion in how to value these options, and Murphy $(1995,1996)$ reports evidence that firms select the method that minimizes the reported ex ante value of the grant. That may indicate that firms perceive greater political costs to high reported compensation. The SEC reforms and section $162(\mathrm{~m})$ may both work in the same direction, increasing the visibility and effective cost of executive pay packages. Simple time differences cannot hope to identify the individual effects of these policies.

Other changes in the personal and corporate income tax code may also influence realized executive compensation. Hall and Liebman (2000) find that options compensation, for example, is responsive to changes in marginal tax rates, and they note that the modest "global" tax advantages of options over cash compensation fell by about one-third between 1992 and 1997. Austan Goolsbee (2000) analyzes the effect of OBRA93's increase in marginal tax rates for the highest income individuals, and argues that this strongly influenced the timing of discretionary income realizations, most notably options exercises by CEOs in late $1992 .^{14}$

\footnotetext{
${ }^{13}$ SEC Rel. No. 33-6962, corrected in Rel. No. 33-6966 on November 9, 1992.

${ }^{14}$ See Hall and Liebman (2000) for an alternative explanation of this phenomenon, based on the high value of the stock market in 1992.
} 
Rose \& Wolfram - page 8

While we report below some data for sample divisions into pre- and post-OBRA93 time periods, this evidence cannot on its own be construed as dispositive on the effect of the section $162(\mathrm{~m})$ cap.

Affected v. unaffected firms: An alternative approach is to compare compensation patterns at firms that were affected by the cap to those at firms with compensation well below the section 162(m) limits. If we could identify firms with "notional" non-deductible compensation in excess of $\$ 1$ million, and compare their ex post compensation behavior to that at firms with notional nondeductible compensation below \$1 million, the difference might tell us how section 162(m) influenced behavior at the first group. This seems to us promising, but raises the question of how to define "affected" and "unaffected" firms. A variety of approaches have been used in the literature. Three principles seem to us to be particularly important in selecting an appropriate definition. First, the definition should not create statistical endogeneity between compensation and affected by using current compensation to define when a firm is affected by the cap. Second, the definition should recognize that actual post-OBRA93 compensation includes any responses firms make to section $162(\mathrm{~m})$. Third, careful consideration should be given to which components of compensation should be included in the determination of affected firms, and at what level of compensation firms begin to act as though they are "affected" by the cap.

The first criterion, avoiding the creation of statistical endogeneity between the compensation measure on the left-hand side of the regression model and the explanatory variable used to define "affected" firms, seems to us to argue against a number of variables used in previous studies. For example, defining affected based on the level of current or even one-period lagged compensation may introduce a statistical correlation between compensation and affected even if no section 162(m) effect exists. The correlation of affected with the error in a compensation levels equation is likely to be positive when affected is defined by level of current compensation. These contemporaneous error correlations may also generate non-zero interaction estimates in specifications with differential slope effects for affected firms (as is effectively the case in the Perry and Zenner (1999) definition of affected). Defining affected by lagged compensation will induce a correlation with the error in levels equations if CEO- or firm-specific effects are not controlled for, and in first-difference regressions or fixed-effect levels regressions if there is "regression to the mean" in executive pay. This raises potential interpretation difficulties with regressions such as Hall and Liebman's (2000), which model the change in log compensation as a function of MILLION, defined as the minimum of (lagged salary compensation/ $\$ 1,000,000,1) .{ }^{15}$ Hall and

\footnotetext{
${ }^{15}$ Hall and Liebman appear to choose a continuous variable in recognition that firms near the cap (e.g. $\$ 950,000$ last year) may hit the cap if they don't change behavior this year, and therefore should be considered affected. The continuous nature of their variable below $\$ 1$ million makes it difficult to interpret as a section $162(\mathrm{~m})$ effect, however. Even if the cap influences the behavior of firms just below the limit, there seems no obvious reason why section $162(\mathrm{~m})$ should have any effect, let alone a differential effect, on firms well below $\$ 1$ million. For example, it seems to us that neither firms paying $\$ 500,000$ nor those paying $\$ 750,000$ should be directly affected by the existence of the cap, but this specification assumes that both groups are affected, and constrains the impact of section 162(m) to be half what it would be for a firm
} 
Rose \& Wolfram - page 9

Liebman attempt to mitigate some of these concerns by using a "difference in differences" estimate, though the effectiveness of this strategy is somewhat limited by the availability of just one year of pre-OBRA93 compensation change data.

The second criterion, avoiding definitions that may be contaminated by firm responses to section 162(m), argues against defining "affected" by reference to post-1993 compensation. If section $162(\mathrm{~m})$ reduced compensation levels, all else equal, firms might appear to be unaffected when in fact their lower compensation is a direct response to the tax cap. If this were true, definitions based on realized post-OBRA93 compensation would tend to bias results against finding the negative policy effect on compensation levels. ${ }^{16}$ Perry and Zenner (1999) define affected firms as those with CEO cash compensation of more than \$1 million in any year during their 1992-1997 sample period. This definition yields affected as a firm characteristic based largely on postOBRA93 compensation. Given this, any compensation level impact of affected is embedded in their model's firm effects, and cannot be separately identified. If this leads firms to be incorrectly characterized, it also may distort the pay-for-performance slope coefficients for affected firms. We believe these considerations argue for using an ex ante measure of which firms are likely to be affected by section $162(\mathrm{~m})$.

The third criterion requires us to consider what compensation components to consider in defining affected firms. The three leading candidates are: salary, cash compensation (defined in our sample as salary and bonus), or total (ex ante) compensation, which includes cash compensation, other compensation, and the Black-Scholes ex ante value of options grants. Basing the definition on salary payments alone, as do Hall and Liebman (2000), seems to us inappropriately narrow. Firms with salaries of less than $\$ 1$ million will nonetheless be affected by section $162(\mathrm{~m})$ if their bonus payments or other compensation components generate sufficient additional compensation to exceed the $\$ 1$ million cap in total. On the other hand, ex ante total compensation seems too broad a definition. The ease and relatively low opportunity cost of qualifying stock options plans suggests to us that if firms are likely to be below the cap in all but expected options awards, their behavior is unlikely to be significantly altered by the presence of section $162(\mathrm{~m})$. We would expect these firms to qualify their options plans and continue on a "business as usual" path. Given these considerations, we argue for using cash compensation as the compensation measure for defining which firms are affected by section $162(\mathrm{~m}) .^{17}$

paying more than $\$ 1$ million for the $\$ 500,000$ group, and three-quarters of that impact for the $\$ 750,000$ group.

${ }^{16}$ Suppose all firms responded to section $162(\mathrm{~m})$ by reducing compensation below $\$ 1$ million. Then using post-OBRA93 compensation, we would find there were no firms affected by the cap, and conclude section 162(m) had no effect.

${ }^{17}$ While we have strong economic reasons to prefer definitions based on cash compensation, we have looked at definitions based on predicted total compensation and salary measures to ensure that our results are not particularly sensitive to this choice. In general, we find that the results based on cash compensation 
Rose \& Wolfram - page 10

We therefore construct the following definition of affected firms. A firm is AFFECTED by section $162(\mathrm{~m})$ in year $\mathrm{t}$ if, in that year, its predicted $C A S H$ compensation is greater than or equal to $\$ 1$ million. To construct our measure of ex ante predicted compensation, we first regress post-1992 $\log C A S H$ compensation on 1991 "base-year" $\log C A S H$ compensation, including a full set of year dummies. Our primary source of compensation data is Standard \& Poor's ExecuComp database, which we supplement with data from Forbes's annual CEO compensation survey and information from proxy statements. Further details are provided in the appendix. This model is then used to construct predicted log compensation in each year. We code firms as AFFECTED if their predicted CEO CASH compensation in a given year is at least \$1 million.

This method of defining which firms are affected by the cap (and when) reduces some of the concerns raised by earlier definitions. ${ }^{18}$ It is not without problems, however. Its reliance on aggregate compensation inflation rates post-OBRA93 means it is not entirely free from potential influences of section 162(m) at the aggregate level (though it is not driven by responses at the firm level). Because of this, and its construction from regression estimates, it remains a noisy measure of whether a firm's notional compensation is sufficiently high to make the cap a possible consideration. We experiment with instrumental variables regression specifications that define affected firms based on actual $C A S H$ compensation of at least $\$ 1$ million in a given year, and instrument for this with our predicted AFFECTED variable.

Using even an ex ante measure to define unaffected firms as a control for underlying trends may lead to problems if the compensation patterns at these firms are inherently different from those of affected firms independent of section 162(m) effects. This would be the case, for example, if larger or higher-paying firms tended to have faster or slower compensation growth rates, or greater pay-for-performance slopes, independent of section 162(m). We would ideally like to use a "differences in differences" approach, in which compensation patterns pre-OBRA93 are used to establish a base relationship between AFFECTED and unaffected firms, and section 162(m) effects are inferred from later changes in that relation. This requires sufficient data pre-OBRA93 to establish the base, however, and implicitly assumes that the pay relation across the two groups is stable over time apart from section $162(\mathrm{~m})$ effects. Unfortunately, salary and options grant data are not broadly available prior to the 1993 implementation of revised SEC proxy disclosure rules. These data limitations reduce the power of the differences-in-differences approach, although we have attempted to discern what we can from pre-OBRA93 compensation patterns in our sample of firms.

are less noisy than are the others, as would be expected if the other compensation measures are less precise in categorizing AFFECTED firms.

${ }^{18}$ By using predicted rather than actual compensation, we should mitigate any direct correlation between $A F F E C T E D$ and the compensation error term, including problems arising from potential mean reversion. 
Qualifiers v. non-qualifiers: Firms differ not only in whether their expected or "notional" pay is likely to exceed the cap, but also in their responses to potential section $162(\mathrm{~m})$ exemptions. There is considerable heterogeneity across firms and over time in decisions to qualify bonus, long-term incentive, or stock options plans for section 162(m) exemption (see Woodlock and Antenucci, 1996, 1997). Table 1 tabulates the fraction of firms in our data set that had qualified various compensation plans as of 1997, overall, as a function of whether they reported using a given compensation type prior to 1994, and as a function of whether they were predicted to be AFFECTED by the deductibility limits. ${ }^{19}$ Firms were most likely to have qualified stock options plans; about two-thirds of the full sample had done so by 1997 . Forty percent had qualified bonus plans, and half this fraction had qualified long-term incentive plans. Part of this variation is due to differences across AFFECTED and unaffected firms. AFFECTED firms were more than twice as likely as unaffected firms to qualify long-term incentive plans and three times more likely to qualify their bonus plan. There is a much smaller gap across AFFECTED and unaffected firms in options plan qualification rates, as would be expected if qualifying stock options plans is relatively simple and low-cost for most firms. Overall, almost $80 \%$ of AFFECTED firms qualified at least one compensation plan for section $162(\mathrm{~m})$ exemption. There are differences in qualification rates that arise from heterogeneity in the composition of executive pay across firms, but these seem important only for firms AFFECTED by section 162(m). When we consider as "eligible" for qualification only those firms that had a positive payment in a given compensation category prior to 1994, roughly three-quarters of eligible $A F F E C T E D$ firms qualified their stock options plans, slightly less than half qualified their bonus plan, and just under forty percent qualified their long-term incentive plan.

As the table indicates, not all AFFECTED firms chose to qualify plans, nor were all firms that qualified plans for section $162(\mathrm{~m})$ exemption predicted to be $A F F E C T E D$ by the deductibility cap. $^{20}$ If qualification alters compensation levels or changes the pay structure independent of level effects, this variation may allow us to distinguish any impact of the deductibility limit from the impact of the qualification requirements themselves.

A difficulty in using qualification decisions to distinguish section 162(m) effects across groups of firms is that these decisions are clearly endogenous. Firms are more likely to qualify their compensation plans if qualification constraints are less onerous (e.g., the firm's existing bonus plans already use an objective formula to specify bonuses, and boards never deviate from those specifications). Firms that expect to exceed the deductible limit are, all else equal, more likely to

${ }^{19}$ By $1997,80 \%$ of the 870 firms with qualification and predicted compensation data were predicted to be AFFECTED by the section $162(\mathrm{~m})$ deductibility limit.

${ }^{20}$ It is interesting that some companies qualify compensation plans for section $162(\mathrm{~m})$ exemption even when their historical executive pay levels suggest that the $\$ 1$ million cap is unlikely to bind. This may be due to factors observable to the firm but not observable to us that suggest the cap will in fact be binding, or to political pressure to appear "tough" on executive compensation decisions regardless of proximity to the $\$ 1$ million deductibility cap. 
Rose \& Wolfram - page 12

qualify compensation plans. This argues for using expected qualification decisions rather than actual decisions to measure their impact.

We construct an instrument for plan qualification from a diffusion model of firm qualification decisions. ${ }^{21}$ We use a Cox proportional hazards framework to estimate the determinants of plan qualification at the firm level. The general specification of the hazard rate, $h_{i j t}$ $\left(t, X_{i t}, Z_{i j}, \beta, \delta\right)$, for firm $i$, plan type $j$ in year $t$ is a function of the year, $t$, time-varying firm characteristics, $X_{i t}$, and an indicator variable for whether the firm reported the use of compensation type $j$ prior to $1994, Z_{i j}$ :

$$
\begin{aligned}
h_{i j t}\left(t, X_{i t}, Z_{i j}, \beta_{j}, \delta_{j}\right) & \equiv \operatorname{Pr}(\text { firm i qualifies plantype } j \text { at time } t \mid \text { firmi has not qualified } j \text { before time } t) \\
& =h_{0 j}(t) \cdot \exp \left(X_{i t} \beta_{j}+\delta_{j} Z_{i j},\right)
\end{aligned}
$$

Our base empirical specification for qualification of compensation plan type $j$ for firm $i$ in industry $k$ at time $t$ is:

$$
\begin{aligned}
& h_{i j k t}\left(t, X_{i t}, Z_{i j}, \beta_{j}, \delta_{j}, \eta_{j k}\right)=h_{0 j}(t) \cdot \exp \left(\beta_{0_{j}}+\beta_{1_{j}} \cdot \ln \left(\operatorname{SALES}_{i t}\right)+\beta_{2 j} \cdot M A R K E T \text { RETURN }{ }_{i t}\right. \\
& +\beta_{3 j} \cdot \text { RETURN ON ASSETS }_{i t}+\beta_{4 j} \cdot \text { MID FISC YEAR } \text { Iit }+\beta_{5 j} \cdot \text { AFFECTED }_{i t} \\
& +\beta_{6 j} \cdot N O T A X_{i t}+\beta_{7 j} \cdot N O T A X_{i t} \cdot \text { AFFECTED }_{i t}+\beta_{8 j} \cdot \text { TURNOVER }+ \\
& \delta_{j} \cdot U S E D \text { COMP TYPE } E_{i j}+\eta_{j k} \text { ) }
\end{aligned}
$$

where $j$ indexes (bonus, stock options, long-term incentive, or stock options and bonus) qualification and $\eta_{\mathrm{jk}}$ is an industry-specific component of the hazard rate for compensation type $j$. Executive Compensation Reports provided us with information on section 162(m) plan qualification dates, which we supplemented where feasible with information from firm proxy statements. The data appendix describes the construction of the variables used in our analysis. We estimate Cox proportional hazard models that allow the baseline hazard $h_{0 \mathrm{j}}(t)$ to vary nonparametrically over time for each type of qualification decision, reflecting variation in survival rates over time and across plan types.

\footnotetext{
${ }^{21}$ Balsam and Ryan (1996) estimate a logit model of 1994 bonus plan qualification on a sample of 155 firms with reported 1992 salary and bonus in excess of \$1 million, including controls for firm sales, expected tax cost of non-compliance, and the historical performance sensitivity of CEO pay at the firm. Our analysis differs from theirs in a number of important ways, most significantly in eliminating the extreme sample selection in their model. See also Porter's (1996) discussion of their analysis.
} 
Rose \& Wolfram - page 13

Firm size (SALES) and profitability rates (MARKET RETURN and RETURN ON ASSETS ) are included to capture possible scale or performance effects on qualification decisions, though there is no particular theoretical model to sign their potential effects. The variable MID FISC YEAR is equal to one for data year 1994 if the company's fiscal year ends in June through November.

Since Compustat's convention assigns these companies to data year 1994 for fiscal years that ended in June through November 1994, OBRA93 did not apply to these companies until data year 1995. We therefore expect them to be much less likely to qualify compensation in data year 1994 . We expect firms with notional compensation that exceeds the cap (AFFECTED) to be more likely to qualify plans, all else equal. ${ }^{22}$ A possible exception would be those with no current tax liability, for which the present discounted cost of losing the tax deduction will be less. We therefore include a control for the $9 \%$ of firm-years in which the firm had no current tax liability (NOTAX), and interact this with AFFECTED. TURNOVER is a variable indicating likely CEO replacement within the next three years. If a CEO is likely to leave office in the near term, deferred compensation may be a more attractive way to meet deductibility limits, and plan restructuring and qualification may be postponed until a new CEO comes on board. We expect firms that do not normally use a given compensation type (e.g., long-term incentive compensation) to be less likely to qualify a plan for that compensation category. The variable USED COMP TYPE equals one if a company recorded a non-zero payment in the given compensation category for any of its top five executives before 1994. Finally, we include an industry-specific effect for groups of two-digit SIC code industries, to capture any differences in industry norms or other industry-correlated effects. The estimation treats companies that had not yet qualified a plan of type $j$ by the 1997 as right-censored. Results are presented in Table 2.

The pattern of point estimates appears relatively robust across different qualification decisions, though the statistical precision of the results sometimes varies. Larger firms (measured by $S A L E S$ ) are more likely to qualify compensation plans of all types, all else equal. The hazard ratio estimates reported in table 2 suggest that doubling firm size increases predicted hazard rates by one-quarter to one-half, moving from a mean hazard rate of .17 to a hazard rate of .24 for bonus plans, for example. Performance variations (either market or accounting returns) do not seem to have any predictive power for qualification decisions. Our control for "exposure," measured by whether the firm USED a given type of compensation prior to OBRA93, is a strong predictor of qualification for long-term incentive plans and stock option plans. The imprecision of its impact on bonus plan qualification may be in part due to the limited variation in this variable for bonus plans. Almost 90 percent of our firms reported bonus payments prior to 1994, in comparison to $71 \%$ awarding stock option grants and $24 \%$ with LTIP payouts.

Results for the remaining variables suggest that qualification decisions are responsive to the expected costs of losing a compensation deduction. AFFECTED firms were two to three times

\footnotetext{
${ }^{22}$ We have explored specifications in which the qualification decision is a function of the amount by which predicted compensation exceeds \$1 million (EXCESS), for either the CEO alone or aggregated over ExecuComp's reported five highest-paid executives. These variables do not add materially to the predictive power of our model once we control for AFFECTED, and the hazard ratios for excess compensation variables generally are extremely close to one.
} 
Rose \& Wolfram - page 14

more likely to qualify bonus, long-term incentive, and a combination of bonus and options plans than were firms not likely to be affected by the deductibility cap, all else equal. The point estimates hint that this effect may be mitigated for firms without current federal income tax liability, but they are not statistically distinguishable from hazard ratios of 1.00. Firms that were not affected by the deductibility limits until data year 1995 were much less likely to qualify plans in 1994, significantly so for all plan types other than LTIPs, further suggesting that firms delayed compliance if regulations were not binding. Finally, firms that might anticipate CEO turnover in the near term $(T U R N O V E R=1)$ are 25 to 30 percent less likely to qualify bonus and stock options plans.

We use the results from these models to construct the predicted probability of qualifying bonus (column 1) and options (column 3) plans for section 162(m) exemption for each firm-year in our sample. These predicted probabilities are then used to instrument for actual qualification decisions when we estimate the effect of qualification status on CEO pay below. Unfortunately, it is extremely difficult to define a convincing set of instruments that influence the qualification decision but do not belong in a compensation equation. Our compensation model follows the norm in the compensation literature by excluding NO TAX, MID FISC YEAR, USED COMP TYPE, and TURNOVER, used to predict qualification decisions. The argument for the exclusion of MID FISC $Y E A R$ is perhaps strongest, although the variable only identifies variation in the decision to qualify in data year 1994 and is equal to one for only 108 observations. For the other three excluded variables, one could construct arguments of varying degrees of plausibility to suggest they belong in a compensation equation. For example, perhaps $N O T A X$ proxies for firm performance in ways not directly controlled for by the performance measures we use. USED COMP TYPE may be correlated with underlying factors that make it more expensive or less convenient for a given firm to use a particular form of compensation and affect its level. To the extent these factors are constant over time at a given firm, including firm-fixed effects (or first-differencing) in the compensation regressions strengthens the exclusion restriction. These caveats do not necessarily imply that the effect of the qualification decision on compensation is unidentified, but identification in the absence of reasonable exclusion restrictions must then rely primarily on functional form assumptions.

\section{Empirical analysis of section $162(\mathrm{~m})$ effects on compensation}

It is instructive to analyze descriptive patterns in the compensation data before we estimate parametric regression models of section 162(m) effects. The initial focus of section 162(m) political rhetoric on "excessive" executive compensation suggests an examination of compensation growth effects. Table 3 explores growth rates for different measures of CEO pay over time and across groups of firms. Rows 1-3 report 1985-1990 data for a sample of firms drawn from the Forbes annual surveys of CEO compensation. $C A S H$ compensation (salary and bonus) and $E X$ POST TOTAL compensation (valuing options if and when they are exercised) are available for this time period. The remaining rows are based on ExecuComp data for 1992-1997, which provides us with additional SALARY and EX ANTE TOTAL compensation measures. 
Rose \& Wolfram - page 15

We first compare growth rates before section 162(m) took effect to those following its implementation (using years through 1993 as the pre-OBRA93 sample). The simple time-series comparison of growth rates is mixed. For the ExecuComp sample, all compensation measures except EX ANTE TOTAL have lower mean growth rates after OBRA93. Inter-period differences are significant at the .10 level or better for all measures except EX POST TOTAL. The Forbes data suggest caution in attributing the aggregate changes between 1992-93 and 1994-1997 to section 162(m), however. For both CASH and EX POST TOTAL, which are available over the entire 19851997 period, the ExecuComp post-OBRA93 growth rates are similar to Forbes pre-OBRA93 growth rates.

We next divide our 1985-1990 and 1994-1997 samples into AFFECTED and unaffected firms. For the post-OBRA93 sample, we define AFFECTED based on predicted compensation in excess of $\$ 1$ million, which is about the $75^{\text {th }}$ percentile of the cash compensation distribution in the early 1990s. Firms paying more than this would be subject to the section $162(\mathrm{~m})$ deductibility limits. Observations in the 1985-1990 Forbes data are defined as affected if their predicted pay exceeds $\$ 850,000$, about the $75^{\text {th }}$ percentile of cash compensation for the 1980-1990 Forbes sample. These firms are in the same part of the compensation distribution as the post-OBRA93 AFFECTED firms, but there is no actual treatment difference between them and their unaffected counterparts. For every measure except $S A L A R Y$, post-OBRA93 mean growth rates were higher for AFFECTED firms than for unaffected firms. This compares to higher EX POST TOTAL compensation growth rates but lower $C A S H$ growth rates for affected firms in 1985-1990. For none of these comparisons, excluding SALARY, are differences between AFFECTED and unaffected firms statistically significant. Thus, in the raw averages, there is no evidence of section 162(m) impact on the level of overall compensation at AFFECTED firms.

The data hint at a possible effect on the SALARY level at AFFECTED firms. Not only are post-OBRA93 $S A L A R Y$ growth rates lower than those in 1992-1993, but firms more likely to hit the tax cap (AFFECTED) also have lower 1994-1997 SALARY growth rates than do firms not expected to exceed the cap, significant at the .01 level. This is broadly similar to $S A L A R Y$ results reported by Hall and Liebman (2000), although their use of lagged actual compensation to define affected firms makes it difficult to discern the extent to which their estimated slower growth is due to mean reversion. Unfortunately, the pre-OBRA93 SALARY growth rates are based on data available only for 1992 and 1993, limiting the meaningfulness of the "differences in differences" test.

To further explore this apparent effect, we analyze the empirical distribution of SALARY. Figures 1 and 2 plot histograms of the SALARY distribution before the tax change (1991-1992) and following its implementation (1995-1997), respectively. We omit the transitional period of 19931994. The 1991-1992 graph suggest a single-peaked SALARY distribution, concentrated in the range of $\$ 100,000$ to $\$ 1.1$ million, with a long thin tail of higher salaries out to about $\$ 3.8$ million. The 1995-1997 graph suggests a rightward-shift in the 1991-1992 distribution, as would be expected from an aggregate increase in nominal CEO salaries. The modal SALARY bin increases from about $\$ 450,000$ to about $\$ 500,000$ between the two periods. Of particular note, however, is 
the bin at \$1 million. There is a substantial increase in the mass at \$1 million in the 1995-1997 sample. This is sufficient to create a secondary peak in the distribution that is not present in the 1991-1992 distribution. This suggests a discrete change in the SALARY-generating process coincident with section $162(\mathrm{~m})$ implementation and focused on its cap of $\$ 1$ million. ${ }^{23}$

An alternative summary of the $S A L A R Y$ distributions is provided in figure 3, which plots kernel density estimates of the empirical SALARY distribution over the 1991-1992 and 1995-1997 periods. Both periods exhibit massing at certain focal points (e.g., $\$ 400,000, \$ 500,000, \$ 700,000)$, suggesting a tendency to set salaries at "round" numbers. The $\$ 1$ million mark seems to be one of those focal points in the 1991-92 salary distribution, albeit not a particularly common one. Several differences are apparent when we look across the 1991-1992 and the 1995-1997 salary distributions. As in the histograms, the 1995-1997 distribution shifts to the right, toward higher salary levels. This shifts the density from lower salary focal points toward higher ones. For example, the estimated mode shifts from $\$ 500,000$ to $\$ 600,000$ between the two periods. The degree of the rightward shift is not uniform across the distribution, however. Importantly, the peak at \$1 million in 1991-1992 does not appear to shift right in the 1995-1997 distribution, but is instead amplified in 1995-1997. The density at this point in 1995-1997 is nearly two-thirds the density at the mode, representing a substantial increase in frequency relative to 1991-1992.

These patterns suggest to us that a $\$ 1$ million salary has become more focal post-OBRA93, perhaps because corporations with notional salaries within range of $\$ 1$ million have been induced by either political or tax costs to maintain salaries within the million-dollar cap. ${ }^{24}$ This interpretation is consistent with the evidence in Table 3 that CEOs of companies affected by OBRA93 limits experienced lower salary growth than CEOs of unaffected firms. It is also consistent with finer cuts of our data that suggest that both mean and median salary growth rates are lowest for executives who were at salaries of $\$ 1$ million in the post-OBRA93 period. ${ }^{25}$

We next divide the sample into two sets of firms: those that had qualified their bonus plans for section 162(m) exemption by 1995 ("qualifiers"), and those that had not. ${ }^{26}$ For firms with

\footnotetext{
${ }^{23}$ We are currently exploring the development of a statistical test of this difference between the preOBRA93 and post-OBRA93 salary distributions.

${ }^{24}$ We cannot tell from the plots alone whether the increased mass at $\$ 1$ million is coming solely from salaries that would otherwise have been above $\$ 1$ million (reflecting section 162(m) salary "cap" effects) or also from salaries that would otherwise have been below $\$ 1$ million (reflecting compression from the establishment of $\$ 1$ million as a focal point for pay levels).

${ }^{25}$ Complementary evidence is provided by Perry and Zenner (1999), who stratify their sample by salary level and year. They find that firms near $\$ 1$ million are less likely to have increased their salary levels over the previous year than are firms paying below $\$ 900,000$.

${ }^{26}$ This categorization is likely to understate differences between the two groups during the 1995-97 period, as the "non-qualifier" group includes both firms for which the cap does not bind (notional compensation is
} 
qualified bonus compensation plans, bonus payments under the plan may continue to be deducted as a corporate tax expense, even if they lead to compensation above the $\$ 1$ million cap. Regardless of their qualification status, however, firms can never deduct salary in excess of $\$ 1$ million. In 1991-1993, the SALARY distributions (not shown) are quite similar across the two groups, with a common mode of $\$ 500,000 .^{27}$ The 1995-1997 salary distributions, however, differ substantially across the two groups of firms. Figure 4 plots kernel density estimates of these distributions. The most dramatic difference is the substantial massing between $\$ 600,000$ and $\$ 1$ million, inclusively, for the qualified group. The salary spike at $\$ 1$ million is higher for both groups of firms after OBRA93 than before (as in Figure 3), but the $\$ 1$ million spike post-OBRA93 is nearly equal to the height of the mode for the qualified group. This suggests that qualification is associated with substantial salary compression around $\$ 1$ million, though this is not necessarily causal.

We also explored "before-and-after" kernel density plots for $C A S H$ compensation, which includes both SALARY and BONUS. Figure 5 plots kernel density estimates after OBRA93 for qualifiers and non-qualifiers. ${ }^{28}$ In general, $C A S H$ compensation varies more across firms than does salary compensation, and its distribution is flatter and much less smooth than the SALARY distribution. In 1995-1997, the flattening of the distribution seems more pronounced for qualifiers, relative to non-qualifiers. This effect, combined with the observed SALARY compression around $\$ 1$ million, is consistent with greater heterogeneity in bonus payments across qualified firms, as might be expected if they were in fact more reliant upon performance-based bonus schemes. ${ }^{29}$ The variance makes it difficult draw strong conclusions about section 162(m) effects from the raw CASH distribution data, however.

We next investigate whether standard compensation regression models detect possible section $162(\mathrm{~m})$ effects. Our first specification models the determinants of compensation levels as a function of firm size and performance, CEO- and year-specific effects, and an indicator variable for whether the firm's notional $C A S H$ compensation is above the $\$ 1$ million cap. The regression model is given by:

below $\$ 1$ million) and those affected by the cap. Moreover, many firms in the non-qualifier group qualify some portion of their compensation after 1995.

${ }^{27}$ The distribution for qualifiers seems shifted slightly to the right relative to that for non-qualifiers, as the secondary and tertiary peaks of the distribution, at $\$ 400,000$ and $\$ 700,000$ for non-qualifiers, are the tertiary and secondary peaks, respectively, for the qualifiers. The mass at $\$ 1$ million also is slightly larger for the qualified group.

${ }^{28}$ We restrict the plots to cash compensation below $\$ 5$ million to allow for sufficient detail in the graphs. Cash compensation has a very long, thin tail, with a maximum observed value of $\$ 102$ million in our full data set.

${ }^{29}$ Other explanations could also be consistent with the observed differences in the distributions. These figures are suggestive, not dispositive, of an OBRA93-related effect. 
Rose \& Wolfram - page 18

$$
\begin{aligned}
\ln \left(\text { Compensation }_{i t}\right)= & \beta_{0}+\beta_{1} \cdot \ln \left(\text { SALES }_{i t}\right)+\beta_{2} \cdot \text { MKT RETURN }_{i t}+\beta_{3} \cdot \text { RETURN ON ASSETS } \\
& +\beta_{40} \cdot \text { AFFECTED }_{i t}+\beta_{41} \cdot \text { AFFECTED }_{i t} \cdot \text { OBRA93 }_{i t} \\
& +\alpha_{i}+\delta_{t}+\varepsilon_{i t}
\end{aligned}
$$

where Compensation for CEO $i$ in year $t$ is either SALARY, CASH, or EXANTE TOTAL compensation, and SALES, MARKET RETURN, and RETURN ON ASSETS are firm-year characteristics. AFFECTED denotes predicted cash compensation of at least $\$ 1$ million, and $O B R A 93$ is one for compensation years that begin after January 1, 1994, when section 162(m) takes effect. This functional form implicitly assumes that any impact of section $162(\mathrm{~m})$ on AFFECTED firms is reflected in a one-time and permanent change in the compensation level. We estimate the model with CEO-specific fixed effects, $\alpha_{i}$, and year-specific fixed effects, $\delta_{t}$. The details on variable construction are provided in the appendix.

In our model, $\beta_{40}$ measures the correlation between high predicted compensation (AFFECTED) and actual compensation levels prior to section $162(\mathrm{~m}) . \beta_{41}$ estimates the effect of section $162(\mathrm{~m})$ on affected firms as the difference between this base correlation and the observed correlation post-OBRA93. If the legislation reduced compensation levels overall it would be reflected in lower year effects for post-OBRA93 years. Differentially lower compensation levels for AFFECTED firms would show up as a negative estimate for $\beta_{41}$. The regressions are estimated over 1993-1997, which in principle allows us to identify $\beta_{41}$ as a post-OBRA93 effect. Our confidence in this "difference-in-differences" type estimate is limited, however, by the fact that we have only one data year (1993) prior to OBRA93 for most firms. ${ }^{30}$

Table 4 reports estimates from this model for $S A L A R Y, C A S H$, and EXANTE TOTAL compensation measures. For each compensation measure, we report three sets of results: OLS and robust regressions that use predicted AFFECTED as the measure of section 162(m) exposure, and instrumental variables regressions that use predicted AFFECTED as an instrument for actual AFFECTED in the regression. ${ }^{31}$ The weights for instrumental variables are those generated by the robust regression results. The weighted IV results suggest that firms likely to be affected by the section $162(\mathrm{~m})$ cap reduce their SALARY compensation level by about $2.5 \%$, and their $C A S H$ and TOTAL compensation levels by $3 \%$ to $4 \%$, all else equal. ${ }^{32}$ These effects are small but statistically distinguishable from zero for $S A L A R Y$ and $C A S H$. These results highlight our dependence on 1993

\footnotetext{
${ }^{30}$ There are two years (1993 and 1994) for firms with fiscal years that end in May through November; see the data appendix for elaboration.

${ }^{31}$ We use the robust regression routine implemented in Stata 6.0.

${ }^{32}$ This result varies with the sample we use. In some subsamples of our data, the effect is estimated as a $10 \%$ to $15 \%$ reduction for all three compensation measures.
} 
Rose \& Wolfram - page 19

data to establish a pre-OBRA93 benchmark. Over the 1994-1997 period, the overall impact of $A F F E C T E D$ on compensation (measured by the sum of coefficients on AFFECTED and AFFECTED* OBRA93) is not significantly different from zero at conventional levels. Thus, the conclusion of a post-OBRA93 dampening in compensation levels depends upon whether one believes that 1993 is generally representative of compensation patterns prior to section 162(m).

Our second specification models changes in compensation as a function of AFFECTED status and decisions to qualify compensation components for section $162(\mathrm{~m})$ exemption. These regressions take the form:

$$
\begin{aligned}
\Delta \ln \left(\text { Compensation }_{i t}\right)= & \beta_{0}+\beta_{1} \cdot \Delta \ln \left(\text { SALES }_{i t}\right)+\beta_{2} \cdot \Delta \text { MKT RETURN } \\
i t & +\beta_{3} \cdot \Delta R E T U R N \text { ON ASSETS } \\
& +\beta_{40} \cdot \text { AFFECTED }_{i t}+\beta_{41} \cdot \text { AFFECTED }_{i t} \cdot{\text { OBRA } 93_{i t}} \\
& +\beta_{5 j} \cdot \text { QUALIFIED }_{i j t}+\beta_{6 j} \cdot \text { QUALIFIED }_{i j t} \cdot \text { AFFECTED }_{i t}+\delta_{t}+\varepsilon_{i t}
\end{aligned}
$$

where $\Delta$ denotes changes between periods $t$ and $t-1$. As before, Compensation is either SALARY, $C A S H$, or EX ANTE TOTAL compensation. In the regressions reported below, we investigate the effect of both bonus and stock options plan qualification $\left(Q U A L I F I E D_{j}, \mathrm{j} \in\right.$ (bonus, stock options)). All regressions include year-specific fixed effects, $\delta_{t}$. This functional form models differential growth rates as a function of whether firms are affected by section 162(m) and their qualification choice. For each compensation measure, we estimate the model on our full sample without any qualification variables (columns 1-3), and on a smaller sample for which we can construct plan qualification variables (columns 4-6 or 4-7). As in the levels estimation, the robust regression estimates use predicted $A F F E C T E D$ in the model. The instrumental variable (IV) estimates use actual AFFECTED and actual QUALIFIED in the model, and instrument for these with predicted $A F F E C T E D$ and predicted $Q U A L I F I E D$ variables. Weighted IV regressions use the weights generated by the robust regressions, which results in a smaller sample size as observations are deleted by the weighting process. We report results for variants of this specification in Table 5 $(S A L A R Y)$, Table $6(C A S H)$, and Table 7 (EX ANTE TOTAL). These are discussed in turn.

The $S A L A R Y$ results in Table 5 suggest that firms with predicted compensation above $\$ 1$ million seem to have slightly lower growth rates prior to OBRA93 than do unaffected firms. Point estimates range from $-0.5 \%$ to $-1.4 \%$, and are marginally significant in most of the specifications. ${ }^{33}$

33 This is about one order of magnitude smaller than the growth rate effect found by Hall and Liebman (2000). Although we cannot exactly replicate their result, our analysis of the data suggests that our change in the definition of AFFECTED is the single most important factor in explaining this difference (reducing 
The results for the post-OBRA93 differential effect are more mixed. In most specifications, the difference is estimated to be small and indistinguishable from zero. An interesting exception is the model reported in column 6 , which includes controls for whether the firm qualified its stock plan for section $162(\mathrm{~m})$ exemption. These results suggest that AFFECTED firms that have not qualified plans for section 162(m) exemption have substantially lower salary growth rates, all else equal, at $4.4 \%$ (standard error, $2.4 \%$ ). Stock plan qualification is itself associated with higher SALARY growth rates $(5.9 \%$, standard error $3.0 \%)$, suggesting that firms with qualified stock options plans tend to be more generous in awarding SALARY increases. We also have experimented with models that control for bonus plan qualification, either in place of or in addition to stock options plan qualification. Estimated bonus plan qualification effects are very noisy and add little to the explanatory power of the model. This is a somewhat unexpected finding, and one that persists across our different compensation measures. We therefore return to an analysis of qualification effects following the discussion of results for table 7. Finally, the control variables for size and performance suggest small scale elasticities (on the order of $4 \%$ ) and virtually no performance sensitivity, as we might expect for $S A L A R Y$ determinants.

Table 6 reports the corresponding results for $C A S H$ compensation. AFFECTED firms do not exhibit differential $C A S H$ compensation growth rates prior to OBRA93, and the results in most specifications suggest little difference post-OBRA93. Again, the notable exception is the specification that controls for stock plan qualification, reported in column 7. AFFECTED firms without qualified stock options plan seem to experience lower growth rates of $C A S H$ compensation, at $-13.6 \%(9.5 \%)$, all else equal. Stock plan qualification is associated with higher growth rates (16.5\%, standard error $11 \%$, for unaffected firms, and just slightly lower on net for AFFECTED firms). Unfortunately, these point estimates are all relatively imprecise, and can be signed away from zero only at $10 \%$ to $15 \%$ confidence levels. As in the $S A L A R Y$ regressions, bonus plan qualification effects are so imprecisely estimated that they cannot be signed away from zero at any conventional levels of significance. The results for the control variables generally conform to those in the literature, with estimated sales elasticities of compensation on the order of $15 \%$ to $20 \%$, and significant performance sensitivities (semi-elasticities around $0.10(0.01)$ for market return and $0.81(.04)$ to $1.83(0.14)$ for return on assets).

TOTAL compensation results, reported in table 7, tell a similar story. TOTAL compensation growth rates do not appear to differ for AFFECTED firms, except in regressions that control for stock options plan qualification (see column 7). AFFECTED firms that do not qualify stock options plans for section $162(\mathrm{~m})$ exemption experience substantially lower growth rates of TOTAL compensation. The point estimate of $-.29(.16)$, or about $25 \%$, has a probability value of .07 in this model. Stock options plan qualification is associated with much higher growth rates (36\%, standard error $22 \%$ ) for unaffected firms; the overall growth rate is somewhat lower than but statistically indistinguishable from this for affected firms that qualify stock options plans (sum the

the coefficient on AFFECTED by more than two-thirds and the coefficient on AFFECTED *OBRA93 by one-half, relative to the Hall and Liebman results). Compensation equation specification changes account for most of the remaining differences. 
Rose \& Wolfram - page 21

coefficients on AFFECTED, AFFECTED*OBRA93, QUALIFICATION, and QUALIFICATION* $A F F E C T E D)$. Again, the control variables for size and performance yield results generally consistent with the literature. The estimated sales elasticities of compensation are much larger than those for $S A L A R Y$ or $C A S H$ measures, at $28 \%(3 \%)$ to $46 \%(6 \%)$, while the performance semielasticities are comparable to (MARKET RETURN) or somewhat smaller than (RETURN ON ASSETS) those in the CASH compensation regressions.

The pattern of results for the specifications that control for compensation plan qualification raise questions of interpretation. As a first pass, the result that growth rates are systematically lower for $A F F E C T E D$ firms that do not qualify compensation for exemption from section 162(m) limits is consistent with expected effects. Since non-qualified compensation above $\$ 1$ million has a higher after-tax cost to the firm, we might expect it to grow less fast, all else equal. This effect seems to be erased by plan qualification, which restores compensation to its original, lower, aftertax cost. This explanation seems most persuasive for the TOTAL compensation regressions, although the point estimates for the growth rate effects are quite large (25\% - 30\% per year). Stock options plan qualification ensures deductibility of options-based pay, which is on average approximately $25 \%$ of EX ANTE TOTAL compensation in our sample. It would not be surprising to see higher compensation at firms that qualify options plans than those that do not.

It is more difficult to match this explanation to the $S A L A R Y$ and $C A S H$ results for AFFECTED firms, however. Stock options plan qualification does not itself alter the after-tax cost of either salary or cash compensation. If changes in the after-tax cost drive compensation choice, we would expect bonus plan rather than stock options plan qualification to have the a direct influence on SALARY and CASH growth rates. Our analysis of the data suggests no evidence of this. Moreover, if firms prefer tax-advantaged forms of compensation, we might expect stock options qualification to induce a shift away from higher-cost salary and bonus toward options-based pay. This would imply a negative stock options qualification effect for AFFECTED firms in the $S A L A R Y$ and $C A S H$ regressions. While the imprecision of the qualification coefficients limits the confidence with which we can sign their effects away from zero, the point estimates all suggest that this is just the opposite of what we observe in the data. ${ }^{34}$

One explanation that would be consistent with the observed pattern of point estimates is that qualification and compensation growth reductions are alternatives means to responding to political pressures on executive compensation. If qualifying a compensation plan for section $162(\mathrm{~m})$ exemption signals that a company is committed to some type of performance-based pay and relaxes political pressures on executive pay, companies that qualify plans are able to pay higher

\footnotetext{
${ }^{34}$ We have explored models of compensation composition (SALARY/CASH, CASH/TOTAL, and $O P T I O N S / T O T A L)$, using specifications similar to those for the compensation level regressions, to investigate this hypothesis directly. It proved difficult to identify determinants of composition measures with any reasonable degree of precision, thus shedding little additional light on how to interpret the qualification results in tables 5-7.
} 
Rose \& Wolfram - page 22

compensation than those that do not. AFFECTED firms that do not qualify a compensation plan may respond to these pressures by reducing the growth rate of their compensation. This would tend to generate negative coefficients on the AFFECTED*OBRA interaction, and positive coefficients for the qualification variables, which is the pattern we observe across tables 5-7. Unfortunately, the imprecision of the point estimates for these coefficients sharply limits our confidence in affirming this interpretation.

Our final set of results analyzes possible section $162(\mathrm{~m})$ impacts on the performance sensitivity of compensation. We use only $C A S H$ and TOTAL compensation, given the very limited responsiveness of $S A L A R Y$ to performance variation in the basic compensation model. Table 8 reports results for a variant of our basic first-difference compensation equation that allows the return slopes to depend upon time (OBRA93) and AFFECTED status. These results are broadly representative of a great many other flexible specifications, including those that allow the performance sensitivity to depend upon qualification decisions as well as AFFECTED status. It is, in general, difficult to pin down significant performance sensitivity interaction terms. In both regressions reported in table $8, A F F E C T E D$ firms seem to exhibit significantly greater performance sensitivity to both market and accounting returns than do unaffected firms. However, the results for the AFFECTED*OBRA93 interaction suggests that the imposition of section $162(\mathrm{~m})$ dampens this this performance sensitivity (significantly so for the TOTAL compensation regressions, and almost completely offsetting the initial impact of AFFECTED for accounting returns). ${ }^{35}$ A reduction in performance sensitivity of executive pay seems counter to the intent of section $162(\mathrm{~m})$, although it could be consistent with decisions to reduce formulaic pay variability in response to reduced Board discretion in compensation awards. The imprecision of these results limits the strength of any conclusions one might wish to draw, however.

\section{Conclusions}

Section $162(\mathrm{~m})$ represented the first broad scale attempt to regulate specific components of executive compensation arrangements apart from disclosure requirements. As we emphasize in sections 1 and 2 of this paper, identifying its effect is complicated by its heterogeneous impact across firms, the limited span of our pre-OBRA93 data, and the difficulties inherent in constructing an appropriate counterfactual from the existing data. Because of this, the empirical effects we can identify conclusively are limited.

\footnotetext{
${ }^{35}$ Perry and Zenner (1999) estimate differential performance slopes using a CEO fixed-effect compensation levels model that defines affected as any firm paying more than $\$ 1$ million in $C A S H$ at some point during their sample period. They estimate interactions of SALES and returns with OBRA93 and OBRA93*affected dummy variables, and conclude that section $162(\mathrm{~m})$ increased the performance sensitivity of compensation. Their model does not estimate differential performance slopes for affected firms prior to OBRA93, however, leading them to interpret positive coefficients on the affected interaction as section 162(m) effects. Our results suggest caution in drawing this conclusion.
} 
Rose \& Wolfram - page 23

Our analysis does suggest that OBRA93's limit on the deductibility of executive pay may have induced firms near the $\$ 1$ million cap to restrain their salary increases. We find evidence of this in the empirical distribution of salary post-OBRA93, as well as in regression analysis that indicates lower salary levels and possibly lower salary growth rates for firms likely to be affected by the compensation deductibility cap. Effects for broader compensation measures are less clear, and the interpretation of our results for section $162(\mathrm{~m})$ effects on $C A S H$ and TOTAL compensation levels and growth rates may well depend as much upon one's priors of the likely effect as on the coefficient estimates themselves.

These conclusions are much less strong than those of other studies, most notably Hall and Liebman (2000) and Perry and Zenner (1999). Attempts to reconcile our results with theirs suggest that the differences are attributable to a combination of different definitions for affected, different compensation equation specifications, and different samples. We have been struck during our analysis of these data by the relative fragility of apparent section $162(\mathrm{~m})$ effects to even modest specification or sample changes. Moreover, we have been unable to identify systematic patterns to account for the variability of the results. While our statistical techniques are not structured to "prove" a null effect, the lack of robust results may be an indication that section 162(m) has had relatively little real impact on overall compensation. This conclusion is consistent with the views expressed by many compensation consultants and corporate directors we have consulted. It suggests that corporate pay decisions may be more insulated from this type of blunt political pressure than it is from the more direct pressure brought to bear at the individual firm level by stakeholder groups (Shackell et. al, 1997) or through the regulatory process (Joskow, Rose, and Wolfram, 1996, and the references therein). 
Rose \& Wolfram - page 24

\section{DATA APPENDIX: VARIABLE DEFINITIONS AND DATA SOURCES}

The data used in this paper were collected from three main sources: Standard \& Poor's ExecuComp and Compustat databases and Executive Compensation Reports data on firm compensation plan responses to section $162(\mathrm{~m})$. We supplemented these sources with data from the annual compensation surveys in Forbes, and with information from firms' proxy statements. We describe our data construction and variable definitions below.

Compensation Data. The primary source of compensation data is the June 1998 version of Standard \& Poor's ExecuComp database. This database follows the 1500 firms in the S\&P 500, Midcap, and Smallcap indices, and contains information on the five highest paid executives for 1837 unique cusip identifiers. We supplement this with information from the June 1997 version of ExecuComp, which adds an additional 681 observations dropped in the June 1998 version of ExecuComp.

Although ExecuComp contains information on the five highest-paid executive officers in a firm, this analysis uses data only on the CEO for each year. We devote considerable attention to ensuring the reported compensation in ExecuComp actually corresponds to the CEO in a given year. Our 1997 ExecuComp dataset recorded as "CEO" compensation the compensation for the individual who was CEO in 1997, for as many earlier years (to 1990) as he was employed by the firm, regardless of his-then current position. The creation of an "as-reported CEO" variable (ceoann) in the June 1998 version of ExecuComp solved part, but not all, of this assignment problem. We used ExecuComp information on dates an individual became CEO or left the CEO position to fill in missing CEO identifiers for 1630 company-years. We relied on tenure information in ExecuComp, Forbes, and proxy statements to delete individuals recorded as "CEO" for years prior to their appointment to that position.

To ensure compensation comparability across observations and over time, we deleted "partial year" observations, in which compensation was reported for CEOs who held office for less than 50 weeks of a given year. CEOs that work partial years are much less likely to qualify for the tax cap because the million dollar deductibility standard applies to the actual amount paid the CEO and does not pro-rate payments for partial years. If we pro-rated for partial years, we would have a misleading indication of the firm's tax liability and if we do not, we will obtain misleading estimates on the coefficients on other correlates with CEO pay. We therefore drop these observations from our analysis.

We additionally removed observations for companies identified as appointing co-CEOs to the top management position, and those with CEOs who were paid through a management service contract to a parent company or any other management service company (typically owned by one or more of the largest shareholders in the corporation). Recorded CEO compensation for these observations is 
Rose \& Wolfram - page 25

unlikely to be generated by the same function that applies to standard employment relationships. After removing observations missing data on CASH compensation, SALES, or MARKET RETURN, we were left with a data set of 6976 observations on 1792 companies over 1993-1997.

Compensation Measures: The analysis uses a variety of compensation measures. Salary measures the ex ante fixed portion of compensation, Bonus reflects short-term bonus payments, and Cash is the sum of Salary and Bonus (following ExecuComp conventions). Total compensation measures include Cash, other annual non-cash compensation, long-term incentive payments, restricted stock grants, stock options, and all other compensation. Ex Ante Total compensation measures total compensation valuing options at the grant date, using ExecuComp's Black-Scholes option valuation. Ex post Total compensation measures total compensation including the net value of options if and when they are exercised.

Cash compensation, and some measures of total compensation, were generally reported on proxy statements prior to 1993. SEC proxy disclosure changes that took effect in late 1993 required companies to report salary and bonus breakdowns, as well as more detailed options information. Thus, while Cash compensation data are available prior to OBRA93, Salary, Bonus, and Ex Ante Total are generally available from 1993 forward. Some earlier salary and bonus decompositions can be constructed from 1993 proxy statements' three-year summary compensation tables for CEOs with positive tenure in 1993.

Base Cash Compensation: We use 1991 Cash compensation as our measure of pre-OBRA93 base cash compensation, where available. Our primary source for this variable is ExecuComp, supplemented by 1990-1992 data from the Forbes' annual compensation surveys, which cover about 800 firms annually, and proxy statements. If 1991 data are not available, we use either 1992 or 1990 Cash compensation data, respectively. These data were available for 1393 firms in our database, accounting for 5764 firm-year observations over 1993-1997.

AFFECTED-predicted: We construct predicted compensation from firms' base-year Cash compensation and the aggregate mean compensation escalation rates for each year. Predictions are constructed from a 1993-1997 regression of the form:

$$
\ln \left(\mathrm{CASH}_{t}\right)=\beta_{0 s} \cdot \ln \left(\text { BASE COMPENSATION }_{s}\right)+\delta_{t}
$$

where $t$ denotes data year (1993-1997), $s$ denotes the year in which BASE COMPENSATION is observed $\left(1991,1992\right.$, or 1990), $\beta_{0 \mathrm{~s}}$ is the escalation coefficient for base year $s$, and $\delta_{t}$ is the escalation coefficient for year $t$. The predicted value of $C A S H$ compensation, given our implicit assumption of log-normality, is: $\mathrm{E}\left(C A S H_{t}\right)=\exp \left(\beta_{0 s} \cdot \ln \left(\right.\right.$ BASE COMPENSATION $\left.\left._{s}\right)+\delta_{t}+.5 \sigma^{2}\right)$. $A F F E C T E D$ is defined to be one for those firm-years in which predicted $C A S H$ compensation is greater than or equal to $\$ 1$ million. This measure is intended to reflect when and which companies are likely to be affected by the million-dollar deductibility limit on executive pay in the absence of any specific compensation response on their part. Given non-decreasing aggregate compensation 
Rose \& Wolfram - page 26

growth rates in our sample, this method implies that once a firm is predicted to reach the $\$ 1$ million threshold, AFFECTED is set equal to one and will remain one thereafter.

EXCESS compensation is defined as $\max (0, E(C A S H)$ - $\$ 1$ million $)$.

TOP5 AFFECTED: For observations in the June 1998 ExecuComp database, we also constructed an indicator of whether the firm was affected based on compensation for the five highest-paid executive officers of the corporation in each year (TOP5 AFFECTED) and the sum of the predicted cash compensation paid to each top 5 executive in excess of $\$ 1$ million (TOP5 EXCESS). These measures were constructed in a similar fashion to AFFECTED and EXCESS, except that predicted compensation regressions were estimated for each payrank $\left(1^{\text {st }}\right.$ through $5^{\text {th }}$ highest-paid executives $)$, then aggregated as appropriate.

Firm Characteristics. We use firm financial information from ExecuComp where available. Sales is total revenues for the firm, Market return is the total return to shareholders (dividend plus capital gains). We supplement financial information with data from the Compustat database where required. Return on assets is defined as net income before extraordinary items and depreciation divided by total assets. Information on federal tax payments, used to construct the NOTAX variable used to predict qualification decisions, is from Computstat.

Industry codes. We include controls for 21 different industry groups in the models estimating compensation plan qualification. These are defined as groups of similar two-digit SIC code industries, using the following assignment:

\begin{tabular}{|l|l|}
\hline Included Two-digit SIC Codes & Industry Description \\
\hline $0-10$ & Agriculture \\
\hline $10,12,14$ & Mining \\
\hline 13 & Oil and gas extraction \\
\hline $15-17$ & Construction \\
\hline 20 & Food \& kindred products \\
\hline 26 & Paper and allied products \\
\hline 27 & Printing and publishing \\
\hline 28 & Chemicals and allied products \\
\hline 29 & Petroleum refining and related industries \\
\hline $21-25,30-32,39$ & Other manufacturing \\
\hline 33,34 & Metals \\
\hline 35 & Machinery and computers \\
\hline 36,38 & Electronic equipment and measuring equipment \\
\hline 37 & Transportation equipment \\
\hline $40-49$ & Transportation, communication, and utilities \\
\hline $50-51$ & Wholesale trade \\
\hline $52-59$ & Retail trade \\
\hline $60-69$ & Financial services \\
\hline $70-79$ & Services 1 \\
\hline $80-89$ & Services 2 \\
\hline
\end{tabular}


Rose \& Wolfram - page 27

Executive Characteristics. Our primary source of information on executives is the ExecuComp database. CEO Tenure is the number of full years in the CEO position at this firm. Age is the CEO's age in years. Because ExecuComp's tenure and age information is incomplete or in some cases obviously incorrect, we supplement or correct it where possible with information from Forbes, firms' proxy statements, and references to various editions of Who's Who.

\section{Section 162(m) Compensation Plan Responses:}

Qualification Decisions. We obtained information on firms' compliance actions from Executive Compensation Reports $(E C R)$, a corporate compensation research firm. ECR follows proxy statements from roughly 1200 firms, though not a proper subset of those followed by ExecuComp. Our data records the year in which firms indicate a shareholder vote to qualify bonus, long-term incentive, and/or stock options compensation plans for section 162(m) exemption.

Predicted Qualification Decisions. We use the hazard model described in section 2 and reported estimates in Table 2 to construct the predicted probability of qualifying each component of the compensation package for section $162(\mathrm{~m})$ exemption. All probabilities are set equal to zero for 1993, the year before section 162(m) regulations were established. The probability that a firm qualified a particular plan in 1994 (the first possible qualification year) is equal to its predicted hazard rate for 1994. Later year $t$ qualification probabilities are constructed by summing the predicted conditional qualification probabilities for all years from 1994 to $t$. For companies that are missing an observation between 1994 and 1997, we use the mean probability of qualifying in that year across all firms in place of the missing value. Our results are not sensitive to this interpolation.

Deferred Compensation. ECR also records years in which a firm's proxy statement indicates executives have deferred compensation as a probable response to section $162(\mathrm{~m})$ deductibility limits. We use the text recorded by ECR to determine whether the deferral is in fact a response to section 162(m) limits on tax-deductible compensation. When there was ambiguity, we consulted the proxy statement to make a final determination. If ECR indicated a deferral in one year, but not in an adjacent year with equivalent compensation liability, we consulted the proxy to confirm the deferral status in the non-reported year or update the deferral variable as appropriate. 
Rose \& Wolfram - page 28

\section{$\underline{\text { Variable List and Descriptions }}$}

Variables referenced in the text and tables, with units in parentheses and their data source in brackets, are listed below.

\section{COMPENSATION}

$S A L A R Y_{t}:$ Base salary earned in year $t(\$ 1,000 \mathrm{~s})$ [Source: ExecuComp]

$B O N U S_{t}$ : Bonus awarded in year $t(\$ 1,000 \mathrm{~s})$ [Source: ExecuComp].

$\mathrm{CASH}_{t}$ : Cash compensation in year $t$, measured by salary and bonus $(\$ 1,000 \mathrm{~s})$ [Source: ExecuComp].

EX ANTE TOTAL $L_{t}$ : Total compensation in year $t$, including salary and bonus, other annual compensation, total value of restricted stock granted, long- term incentive payments, the Black-Scholes valuation of options grants in year $t$, and all other compensation (\$1,000s) [Source: ExecuComp].

EXPOST TOTAL $L_{t}$ : Total compensation in year $t$ including salary and bonus, other annual compensation, total value of restricted stock granted, long-term incentive payments, net value of options exercised, and all other compensation $(\$ 1,000$ s) [Source: ExecuComp].

$\mathrm{BASE} \mathrm{CASH}_{0}$ : CASH compensation in 1991, if available. If not, 1992 or $1990 \mathrm{CASH}$ compensation was used (\$1,000s) [Source: ExecuComp, Forbes compensation surveys, or proxy statements, respectively].

\section{$\underline{\text { SECTION 162(M) POLICY }}$}

AFFECTED - actual: Equals one if actual CASH compensation in year $t$ is equal to or greater than $\$ 1$ million, else zero. $(0,1)$. [Source: ExecuComp].

AFFECTED $D_{t}$ - predicted: Equals one if predicted $C A S H$ compensation in year $t$ is equal to or greater than $\$ 1$ million, else zero. $(0,1)$. [Source: Regression estimates described in the data appendix]

$O B R A 93_{t}$ : Equals one if compensation in year $t$ is subject to the section $162(\mathrm{~m})$ deductibility limits, else zero. Section $162(\mathrm{~m})$ applies to compensation paid in tax years beginning January 1, 1994, or later. Given ExecuComp and Compustat dating conventions, this implies an effective date of data year 1994 for all companies except those with fiscal years ending in the months May through November. For companies 
Rose \& Wolfram - page 29

with May through November fiscal years, section $162(\mathrm{~m})$ takes effect with data year 1995. $(0,1)$ [Source: Authors' calculations].

QUALIFIED BONUS $S_{t}$ : Equals one if a company took the necessary steps to qualify its bonus plan prior to or in year $t$, else zero. Equals zero in all other cases. $(0,1)$ [Source: Executive Compensation Reports].

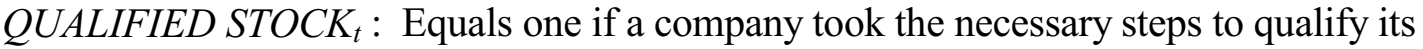
stock plan prior to or in year $t$, else zero. $(0,1)$ [Source: Executive Compensation Reports].

QUALIFIED LTIP $_{t}$ : Equals one if a company took the necessary steps to qualify its longterm incentive plan prior to or in year $t$, else zero. $(0,1)$ [Source: Executive Compensation Reports].

PRED QUALIFIED BONUS : Equals the predicted probability of qualifying the firm's bonus plan by year $t$. [Source: Hazard model estimates in table 2.]

PRED QUALIFIED LTIP $_{t}$ : Equals the predicted probability of qualifying the firm's longterm incentive plan by year $t$. [Source: Hazard model estimates in table 2.]

PRED QUALIFIED STOCK : Equals the predicted probability of qualifying the firm's bonus plan by year $t$. [Source: Hazard model estimates in table 2.]

DEFERRED $D_{t}$ : Equals one if a company reported that it had asked its CEO to defer all or part of compensation in excess of $\$ 1,000,000$ in year $t$ to maintain deductibility under section 162(m), else zero. $(0,1)$ [Source: Executive Compensation Reports and proxy statements].

\section{FIRM AND CEO CHARACTERISTICS}

SALES $S_{t}$ : Net sales in year $t$. (\$ MM) [Source: ExecuComp and Compustat].

MARKET RETURN $N_{t}$ : Return on shareholders equity over year $t$. [Source: ExecuComp].

RETURN ON ASSETS : Net income (excluding extraordinary items) divided by total assets in year $t$. [Source: Compustat].

NO TAX $X_{t}$ : Equals one if a company reported zero or negative federal corporate income tax payments in year $t$, else zero. $(0,1)$ [Source: Compustat].

MID FISC YEAR $R_{t}$ : Equals one if a company has a fiscal year that ends in June through November for data year 1994, else zero. (0,1) [Source: Compustat]. 
Rose \& Wolfram - page 30

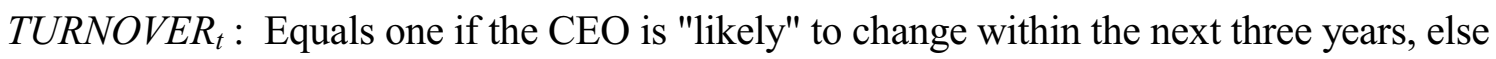
zero. "Likely" is defined as having a CEO aged 62 or more in the current year or having actual CEO turnover within the three years following the current year. $(0,1)$ [Source:

ExecuComp, supplemented by Forbes and proxies for age data].

USED COMP TYPE $E_{t}$ : Equals one if the data record a non-zero payment in the relevant compensation category (Bonus, Stock Options, Long-term Incentive Plans, Stock Options and Bonus) before 1994 for any of the top five executives (for companies in the June 1998 ExecuComp database) or for the CEO (for companies only in our 1997 ExecuComp supplement), else zero. (0,1) [Source: ExecuComp]. 
Rose \& Wolfram - page 31

\section{Appendix Table 1}

\section{Descriptive Statistics}

$(\mathrm{N}=\mathbf{5 7 6 0})$

\begin{tabular}{|l|c|c|}
\hline \multicolumn{1}{|c|}{ Variable } & Mean & $\begin{array}{c}\text { Standard } \\
\text { Deviation }\end{array}$ \\
\hline SALARY $(\$ 000 s)$ & 570 & 297 \\
\hline CASH $(\$ 000 s)$ & 1145 & 1961 \\
\hline EXANTE TOTAL $(\$ 000 s)$ & 2719 & 5661 \\
\hline EX POST TOTAL $(\$ 000 s)$ & 2558 & 6721 \\
\hline SALES $(\$ M M)$ & 3749 & 9594 \\
\hline MARKET RETURN & .21 & .45 \\
\hline RETURN ON ASSETS & .04 & .09 \\
\hline AFFECTED - actual & .38 & .49 \\
\hline AFFECTED - predicted & .49 & .50 \\
\hline QUALIFIED & .24 & .42 \\
BONUS $(n=3725)$ & & .31 \\
\hline QUALIFIED & .10 & .48 \\
LTIP $(n=3725)$ & & \\
\hline QUALIFIED STOCK & .35 & .28 \\
OPTIONS $(n=3725)$ & & .27 \\
\hline QUALIFICATION HAZARD MODEL SAMPLE: $\mathbf{N}=\mathbf{3 0 8 7}$ \\
\hline NO TAX & .09 & .48 \\
\hline MID-FISCAL YEAR & .08 & .19 \\
\hline TURNOVER & .45 & .45 \\
\hline USED BONUS & .96 & .36 \\
\hline USED LTIP & .28 & .84 \\
\hline USED OPTIONS & .32 & \\
\hline PREDICTED QUALIFIED & & \\
BONUS $(n=2453)$ & & \\
\hline PREDICTED QUALIFIED & & \\
STOCK $(n=2453)$ & & \\
\hline
\end{tabular}


Rose \& Wolfram - page 32

\section{REFERENCES}

Baker, Terry A. 1999. "Options Reporting and the Political Costs of CEO Pay." Journal of Accounting, Auditing, and Finance 14:2 (Spring): 124-145.

Balsam, Steven and David H. Ryan. 1996. "Response to Tax Law Changes Involving the Deductibility of Executive Compensation: A Model Explaining Corporate Behavior." Journal of the American Taxation Association 18 (Supplement): 1-12.

Barro, Jason R. and Robert J. Barro. 1990. "Pay, Performance and Turnover of Bank CEOs." Journal of Labor Economics 8 (October): 448-81.

Birnbaum, Jeffrey H. 1992. "From Quayle to Clinton, Politicians Are Pouncing on the Hot Issue of Top Executives’ Hefty Salaries." Wall Street Journal. January 15: A14.

Bok, Derek. 1993. The Cost of Talent. New York: The Free Press.

Crystal, Graef. 1991. In Search of Excess. New York: Norton.

. 1995. "Need a Good Laugh? Look at Caps on Executive Pay." Los Angeles Times. May 21: D2.

Geddes, R. Richard. 1997. "Ownership, Regulation, and Managerial Monitoring in the Electric Utility Industry." Journal of Law and Economics 40 (April): 261-288.

Goolsbee, Austan. 2000. "What Happens When You Tax the Rich? Evidence from Executive Compensation." Journal of Political Economy 108(April): 352-378.

Hadlock, Charles J. and Gerald B. Lumer. 1997. "Compensation, Turnover, and Top Management Incentives: Historical Evidence." Journal of Business 70 (April): 153-187.

Hall, Brian J. and Jeffrey B.Liebman. 1998. "Are CEOs Really Paid Like Bureaucrats?” Quarterly Journal of Economics 107:3 (August): 653-691. . 2000. "The Taxation of Executive Compensation.” In James Poterba, ed., Tax Policy and the Economy, volume 14. Cambridge: NBER \& MIT Press, pp. 1-44.

Haubrich, Joseph G. 1994. "Risk Aversion, Performance Pay, and the Principal-Agent Problem." Journal of Political Economy 102: 2 (April): 258-276.

Hubbard, Glenn and Darius Palia. 1995. " Executive Pay and Performance: Evidence from the U.S. Banking Industry." Journal of Financial Economics 39(1): 105-30. 
Rose \& Wolfram - page 33

Jensen, Michael C. and Kevin J. Murphy. 1990. "Performance Pay and Top-Management Incentives." Journal of Political Economy 98 (April): 225-264.

Johnson, Marilyn F., Susan Porter and Margaret B. Shackell. 1997. "Stakeholder Pressure and the Structure of Executive Compensation.” Mimeo, University of Michigan Business School.

Joskow, Paul L, Nancy L. Rose and Andrea Shepard. 1993. "Regulatory Constraints on CEO Compensation." Brookings Papers on Economics Activity: Microeconomics, 1-58.

Joskow, Paul L, Nancy L. Rose and Catherine D. Wolfram. 1996. "Political Constraints on Executive Compensation: Evidence From the Electric Utility Industry." RAND Journal of Economics 27 (Spring): 165-182.

Klassen, Kenneth and Amin Mawani. 1998. "The Impact of Financial and Tax Reporting Incentives on Option Grants to Canadian CEOs." Mimeo, University of Waterloo, Ontario, Canada, June.

Lewellen, Wilbur, Taewoo Park, and Byung Ro. 1995. "Executive Stock Option Compensation: The Corporate Reporting Decision." Managerial and Decision Economics 16: 633-647.

Lublin, Joann S. 1994. "Firms Forfeit Tax Break to Pay Top Brass \$1 Million-Plus." Wall Street Journal, (April 21): B1, B3.

Murphy, Kevin J. 1995. “Politics, Economics, and Executive Compensation.” University of Cincinnati Law Review 63: 713-748.

. 1996. "Reporting Choice and the 1992 Proxy Disclosure Rules." Journal of Accounting, Auditing and Finance 11 (Summer): 497-515.

. 2000. "Executive Compensation.” In O. Ashenfelter \& D. Card, eds., Handbook of Labor Economics, vol. 3 Amsterdam: North-Holland.

Perry, Tod and Marc Zenner. 1999. "Pay for Performance? Government Regulation and the Structure of Compensation Contracts." Mimeo, University of North Carolina Chapel Hill.

Porter, Susan L. 1996. "Discussion of Response to Tax Law Changes Involving the Deductibility of Executive Compensation: A Model Explaining Corporate Behavior." Journal of the American Taxation Association 18 (Supplement): 13-17.

Prevost, Andrew K. and John D. Wagner. 1999. "Impact of the 1992 Changes in the SEC Proxy Rules and Executive Compensation Reporting Requirements." Mimeo, Massey University, Palmerston North, New Zealand, September. 
Rose \& Wolfram - page 34

Rose, Nancy and Catherine Wolfram. 2000. "Has the 'Million-Dollar Cap' Affected CEO Pay?" American Economic Review, Papers and Proceedings 90 (May): 197-202.

Rosen, S. 1992, "Contracts and the Market for Executives," in Lars Wernin and Hans Wijkander, eds., Contract Economics, Oxford, UK: Basil Blackwell.

Stigler, George. 1971. "The Theory of Economic Regulation." Bell Journal of Economics 2 (Spring): 3-21.

Tversky, Amos and Daniel Kahneman. 1974. "Judgment under Uncertainty: Heuristics and Biases." Science, 185: 1124.

Wolfram, Catherine D. 1998. "Increases in Executive Pay Following Privatization." Journal of Economics and Management Strategy, 7 (Fall): 327-361.

Woodlock, Peter, and Joseph W. Antenucci. 1996. "Corporate Responses to Executive Compensation Deductibility Limits," Tax Notes November 11: 705-709.

Woodlock, Peter, and Joseph W. Antenucci. 1997. "Update: Corporate Responses to Executive Compensation Deductibility Limits," Tax Notes October 13: 221-226. 
Rose \& Wolfram - page 35

FIGURE 1: SALARY Histogram, 1991-1992

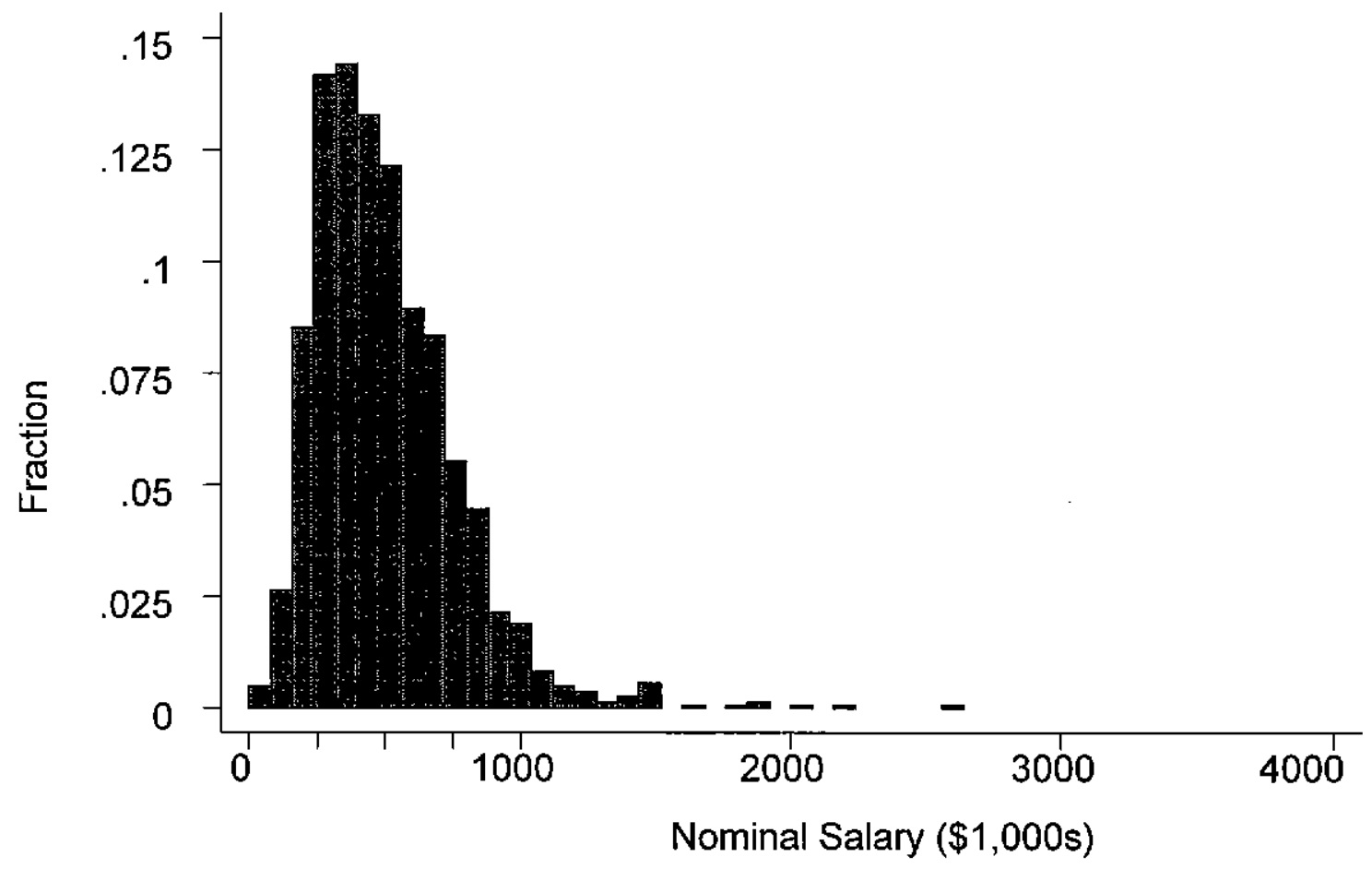


Rose \& Wolfram - page 36

FIGURE 2: SALARY Histogram, 1995-1997

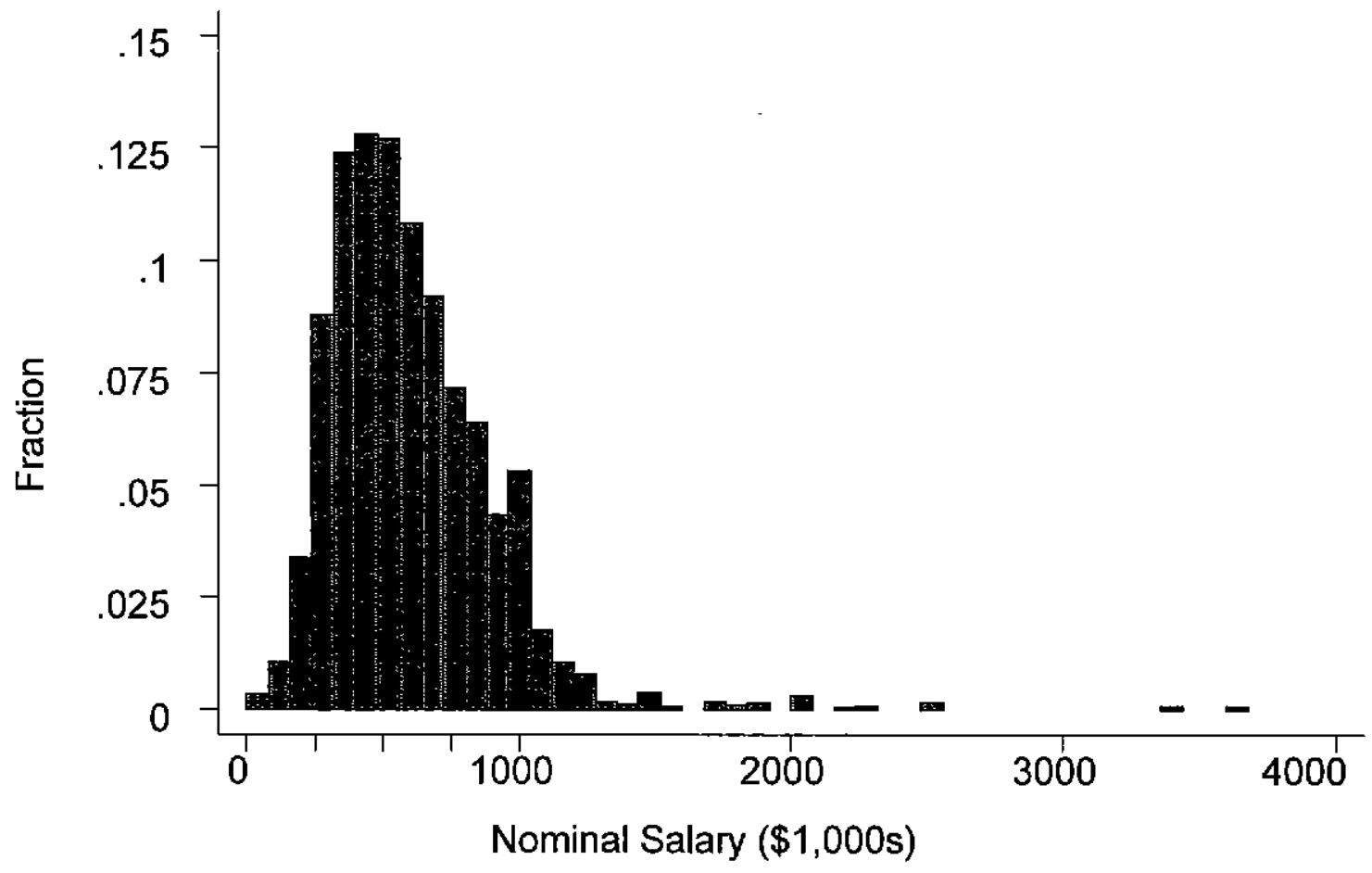


Rose \& Wolfram - page 37

FIGURE 3: SALARY Distribution, Kernel Density Estimates, 1991-1992 v. 1995-1997

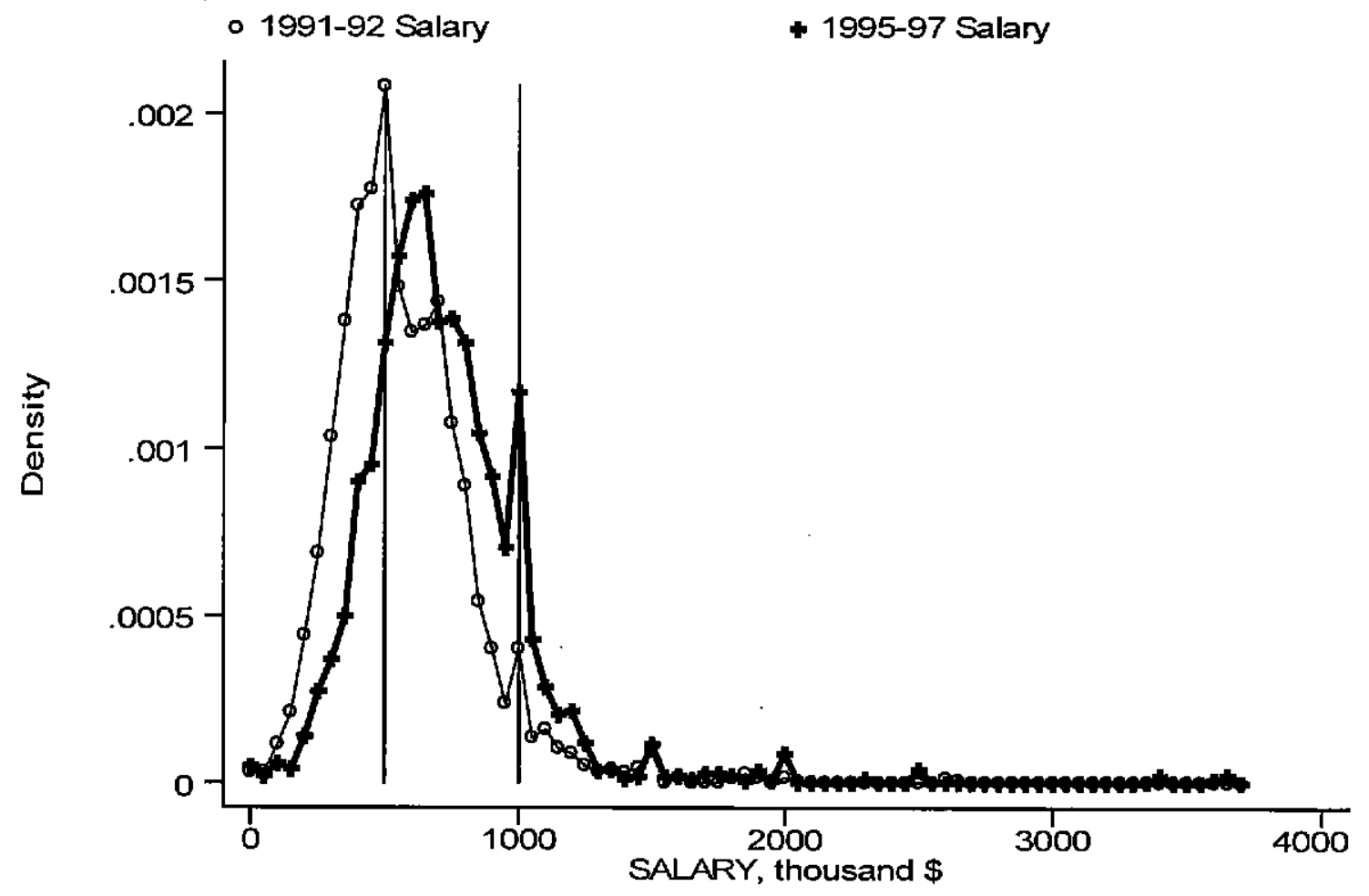


Rose \& Wolfram - page 38

FIGURE 4: 1995-1997 SALARY Distribution by 1995 Qualification Status

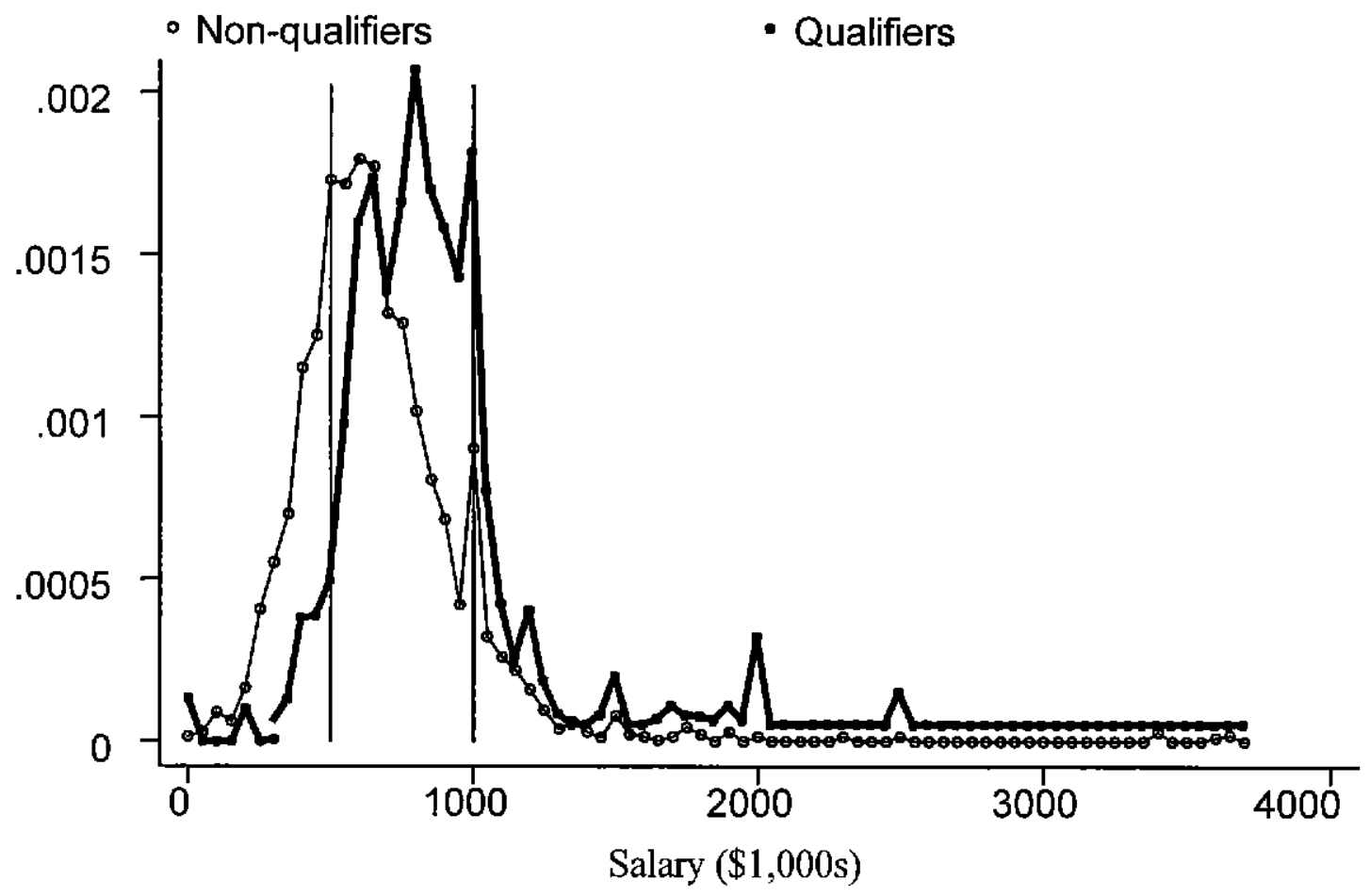


Rose \& Wolfram - page 39

FIGURE 5: 1995-1997 CASH Distribution by 1995 Qualification Status

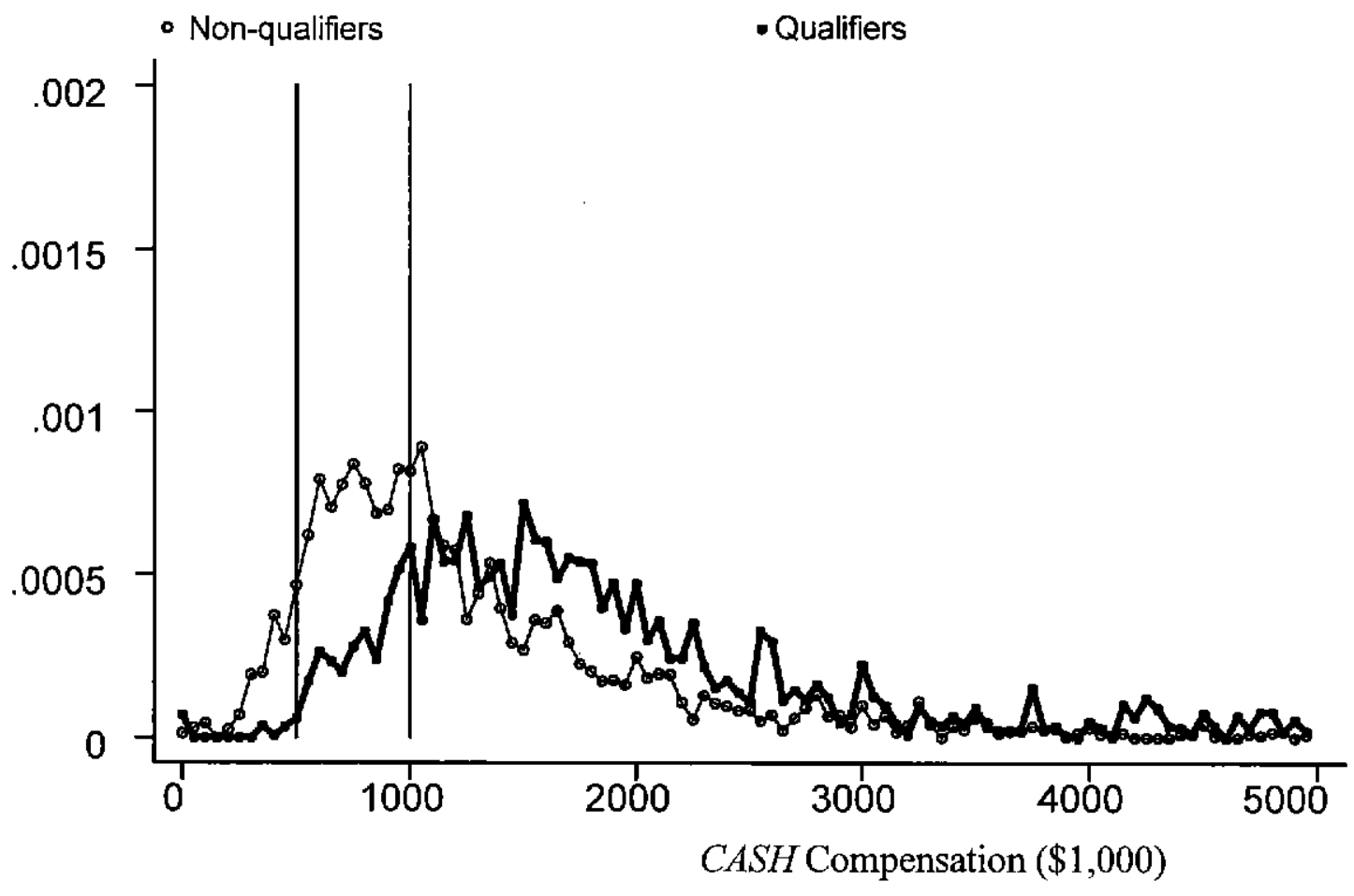




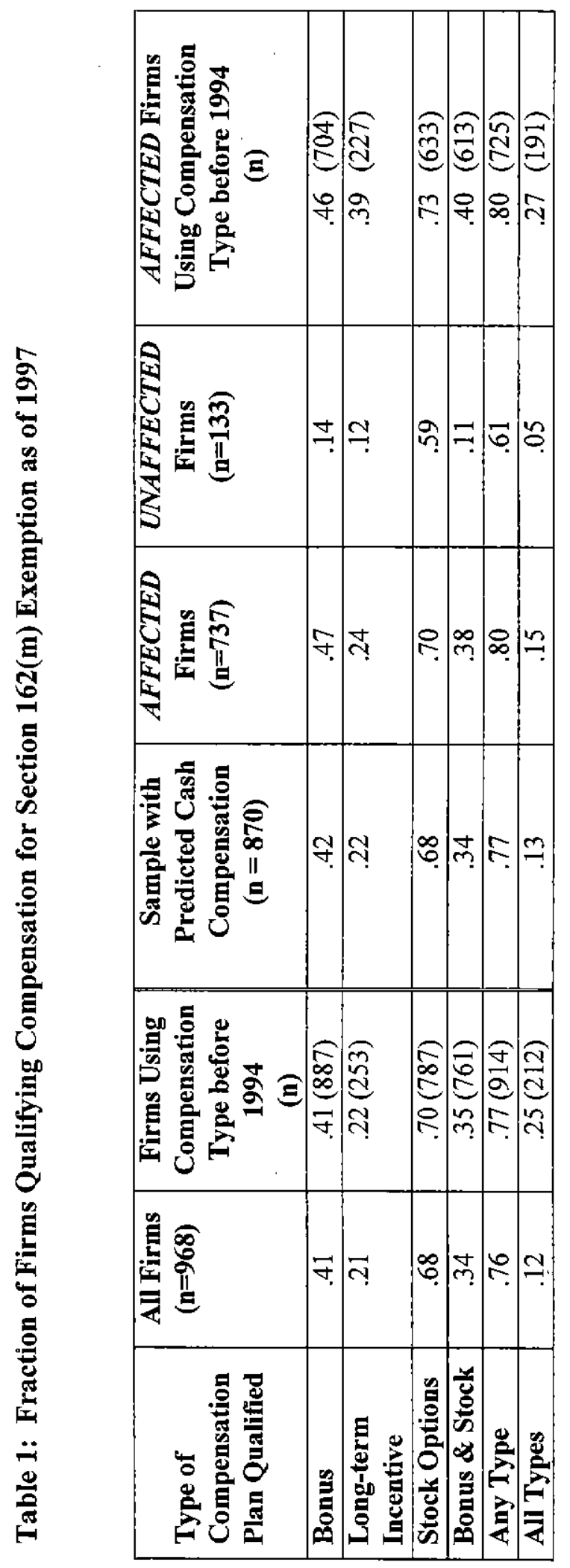


Table 2: Cox Proportional Hazard Models: 1994-1997 Compensation Plan Qualification

\begin{tabular}{|l|c|c|c|c|}
\hline Plan type: & BONUS & LTIP & $\begin{array}{c}\text { STOCK } \\
\text { OPTIONS }\end{array}$ & $\begin{array}{c}\text { OPTIONS \& } \\
\text { BONUS }\end{array}$ \\
\hline In(SALES) & $1.39^{*}$ & $1.33^{*}$ & $1.27^{*}$ & $1.52^{*}$ \\
& $(.09)$ & $(.11)$ & $(.07)$ & $(.11)$ \\
\hline MARKET & .75 & .88 & 1.04 & .96 \\
RETURN & $(.16)$ & $(.24)$ & $(.15)$ & $(.20)$ \\
\hline RETURN ON & 4.40 & 1.55 & .94 & 2.48 \\
ASSETS & $(5.73)$ & $(2.64)$ & $(.90)$ & $(3.27)$ \\
\hline MID FISC YEAR & $.12^{*}$ & .64 & $.14^{*}$ & $(\mathrm{a})$ \\
& $(.07)$ & $(.40)$ & $.07)$ & \\
\hline AFFECTED & $3.28^{*}$ & $1.61^{*}$ & 1.21 & 3.20 \\
& $(.70)$ & $(.43)$ & $(.44)$ & $(.86)$ \\
\hline NO TAX & 1.41 & .86 & 1.20 & 1.24 \\
& $(.81)$ & $(.32)$ & $(.44)$ & $(.96)$ \\
\hline NO TAX ${ }^{*}$ & .52 & $(\mathrm{~b})$ & .68 & .77 \\
AFFECTED & $(.33)$ & & $.30)$ & $(.63)$ \\
\hline TURNOVER & $.70^{*}$ & .96 & $.74^{*}$ & $.73^{*}$ \\
& $(.10)$ & $(.17)$ & $(.09)$ & $(.11)$ \\
\hline USED COMP & 1.12 & $2.65^{*}$ & $1.45^{*}$ & 1.34 \\
TYPE & $(.38)$ & $(.50)$ & $(.24)$ & $(.29)$ \\
\hline Observations Used & 2027 & 2281 & 1845 & 2213 \\
in Estimation & & & & \\
\hline Likelihood Ratio & -766.16 & -509.90 & -992.26 & -667.67 \\
\hline
\end{tabular}

Table reports hazard ratios (standard errors) from Cox proportional hazard models. $*$ denotes a $p$-value of .10 or less for the test hazard ratio ${ }_{\mathrm{j}}=1.00$.

(a): No firms with MID FISC YEAR qualified stock \& bonus plans in 1994, so this hazard ratio would be identically zero in the model.

(b) NOTAX and NOTAX*AFFECTED are perfectly collinear for firms qualifying their LTIP plans. 
Rose \& Wolfram - page 42

Table 3: Mean Annual Growth Rates in Same-CEO Compensation

\begin{tabular}{|c|c|c|c|c|}
\hline Compensation Measure: & SALARY & $\overline{C A S H}$ & $\begin{array}{c}E X A N T E \\
\text { TOTAL }\end{array}$ & $\begin{array}{c}\text { EXPOST } \\
\text { TOTAL }\end{array}$ \\
\hline $\begin{array}{l}\text { Pre-OBRA93: } \\
\text { 1985-1990 }(n=2249)\end{array}$ & -- & .147 & -- & .387 \\
\hline$U N A F F E C T E D$ & -- & .157 & -- & .348 \\
\hline$A F F E C T E D$ & -- & .134 & -- & .444 \\
\hline $1992-1993(n=620-1635)$ & .112 & ".198 & .291 & .726 \\
\hline $\begin{array}{l}\text { Post-OBRA93: } \\
\text { 1994-1997 }(n=2977)\end{array}$ & .077 & .143 & .418 & .593 \\
\hline UNAFFECTED & .085 & .136 & .410 & .532 \\
\hline AFFECTED & .071 & .149 & .426 & .650 \\
\hline
\end{tabular}

1985-1990 data from Forbes; 1992-1997 data from ExecuComp. 







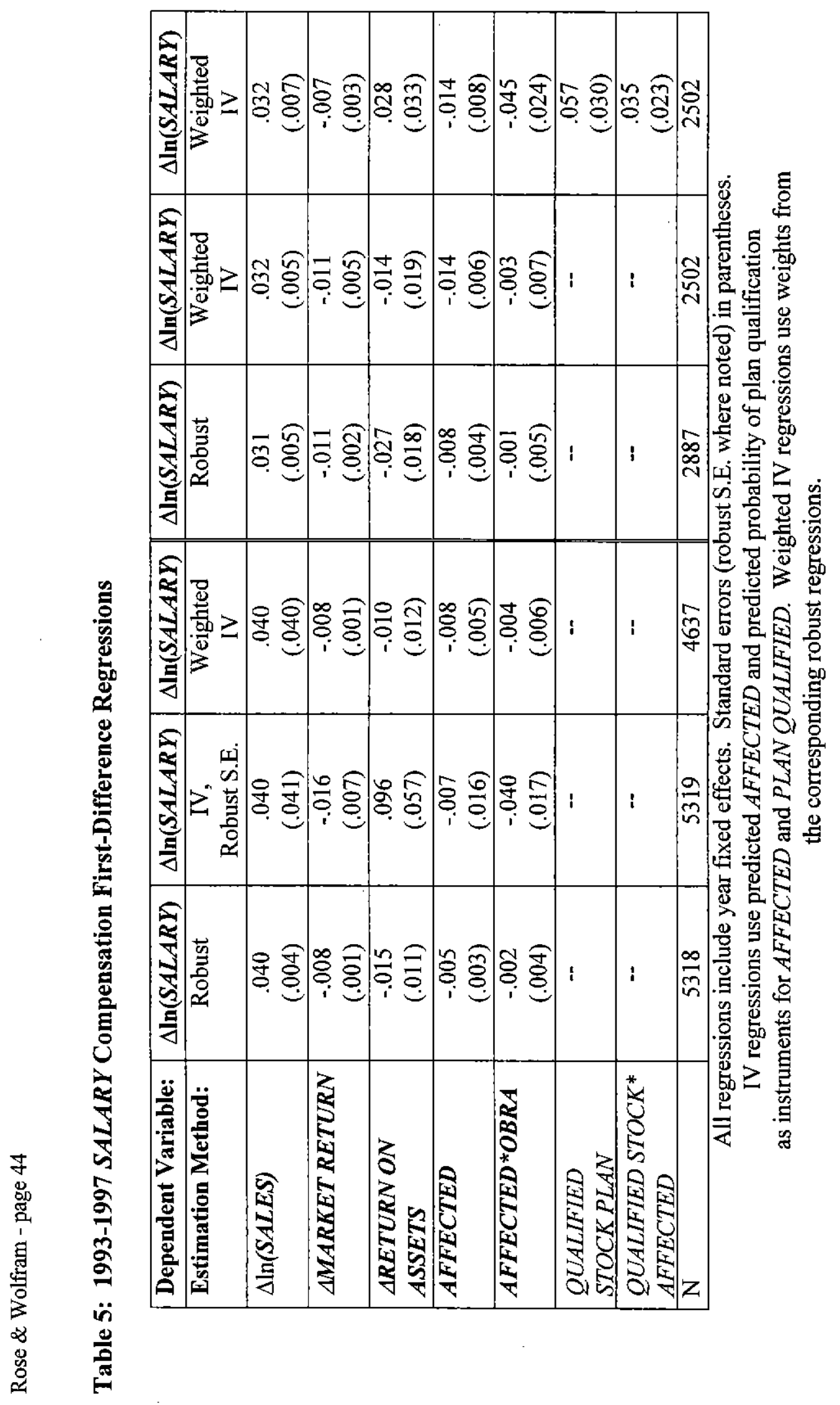




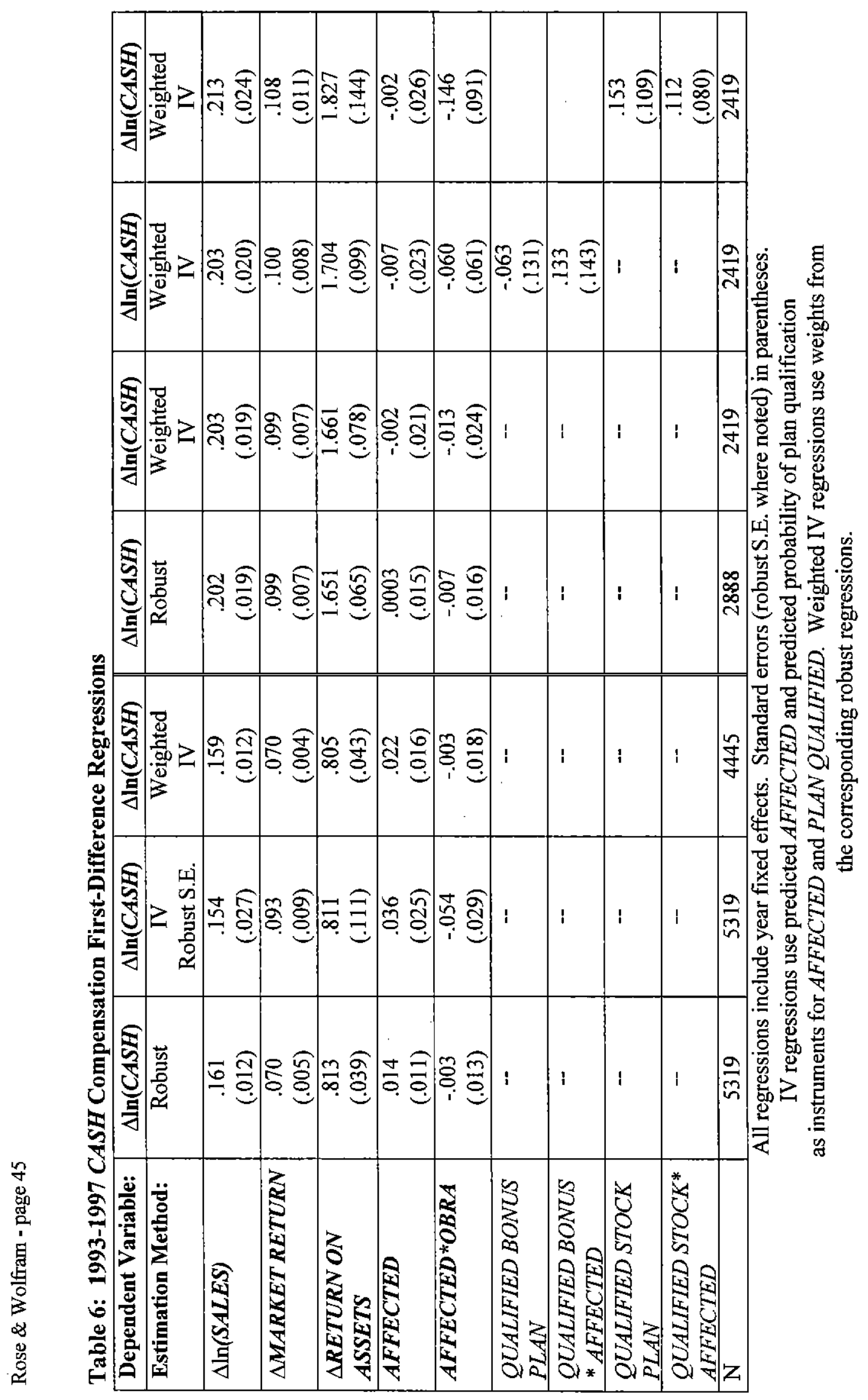




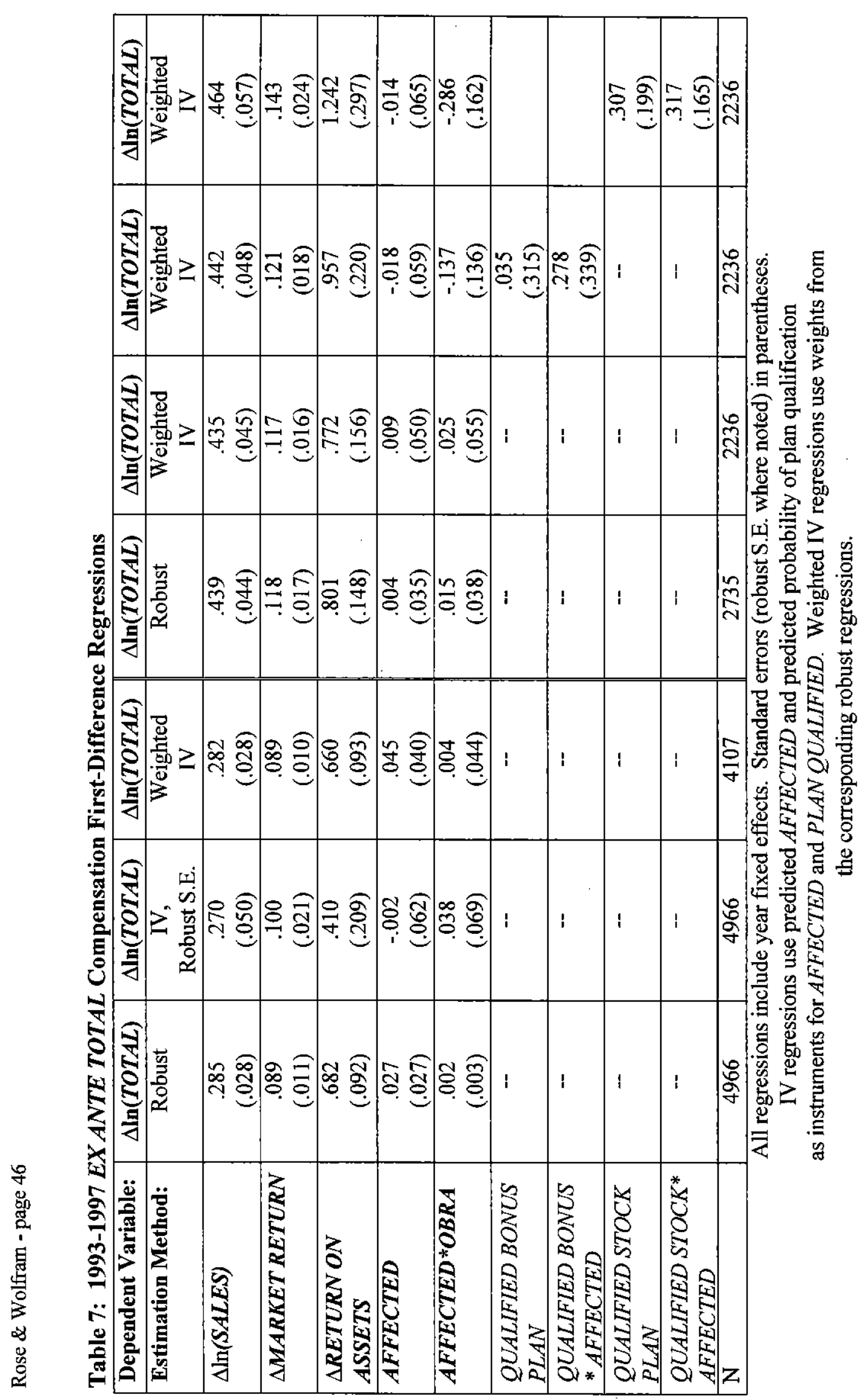


Table 8: 1993-1997 Performance-Sensitivity Regressions

\begin{tabular}{|c|c|c|}
\hline Variable & $\Delta \ln (C A S H)$ & $\triangle \ln (E X A N T E T O T A L)$ \\
\hline$\Delta \ln (S A L E S)$ & $\begin{array}{l}.218 \\
(.029)\end{array}$ & $\begin{array}{l}.437 \\
(.067)\end{array}$ \\
\hline$\triangle M A R K E T$ RETURN & $\begin{array}{l}.045 \\
(.029)\end{array}$ & $\begin{array}{l}-.108 \\
(.075)\end{array}$ \\
\hline$\triangle M A R K E T$ RETURN $N^{*} O B R A$ & $\begin{array}{l}.017 \\
(.037)\end{array}$ & $\begin{array}{l}.126 \\
(.089)\end{array}$ \\
\hline $\begin{array}{l}\triangle M A R K E T R E T U R N^{*} \\
\text { AFFECTED }\end{array}$ & $\begin{array}{l}.212 \\
(.074)\end{array}$ & $\begin{array}{l}.722 \\
(.207)\end{array}$ \\
\hline $\begin{array}{l}\triangle M A R K E T R E T U R N^{*} \\
O B R A^{*} A F F E C T E D\end{array}$ & $\begin{array}{l}-.099 \\
(.087)\end{array}$ & $\begin{array}{l}-.442 \\
(.222)\end{array}$ \\
\hline$\triangle R E T U R N$ ON ASSETS & $\begin{array}{c}.664 \\
(.232)\end{array}$ & $\begin{array}{l}.275 \\
(.620)\end{array}$ \\
\hline $\begin{array}{l}\triangle R E T U R N \text { ON ASSETS* } \\
\text { OBRA }\end{array}$ & $\begin{array}{l}-.183 \\
(.372)\end{array}$ & $\begin{array}{l}.665 \\
(.820)\end{array}$ \\
\hline $\begin{array}{l}\triangle R E T U R N \text { ON ASSETS* } \\
\text { AFFECTED }\end{array}$ & $\begin{array}{l}3.625 \\
(.837)\end{array}$ & $\begin{array}{l}11.482 \\
(3.670)\end{array}$ \\
\hline $\begin{array}{l}\text { पRETURN ON ASSETS* } \\
\text { OBRA *AFFECTED }\end{array}$ & $\begin{array}{c}-.319 \\
(1.178)\end{array}$ & $\begin{array}{r}-10.429 \\
(3.838)\end{array}$ \\
\hline AFFECTED & $\begin{array}{l}-.010 \\
(.031)\end{array}$ & $\begin{array}{l}-.008 \\
(.071)\end{array}$ \\
\hline$A F F E C T E D * O B R A$ & $\begin{array}{l}-.212 \\
(.123)\end{array}$ & $\begin{array}{l}-.341 \\
(.193)\end{array}$ \\
\hline QUALIFIED STOCK PLAN & $\begin{array}{c}.209 \\
(.142)\end{array}$ & $\begin{array}{c}.343 \\
(.227)\end{array}$ \\
\hline $\begin{array}{l}\text { QUALIFIED STOCK PLAN } \\
\text { AFFECTED }\end{array}$ & $\begin{array}{l}.152 \\
(.103)\end{array}$ & $\begin{array}{c}.329 \\
(.184)\end{array}$ \\
\hline$N$ & 2420 & 2239 \\
\hline
\end{tabular}

Weighted instrumental variable estimates.

Standard errors in parentheses. 